\title{
Mid-late Holocene fluvial aggradational landforms and morphometric investigations in the southern front of the Shillong plateau, NE India
}

\author{
Watinaro Imsong ${ }^{1, *} \bullet$, Swapnamita Choudhury ${ }^{2}$ and Sarat Phukan ${ }^{3}$ \\ ${ }^{1}$ Department of Geology, Nagaland University, Kohima 797 001, India. \\ ${ }^{2}$ Wadia Institute of Himalayan Geology, Dehradun, India. \\ ${ }^{3}$ Department of Geological Sciences, Gauhati University, Assam, India. \\ *Corresponding author. e-mail: imsongnar@gmail.com
}

MS received 25 May 2018; revised 26 July 2018; accepted 14 October 2018; published online 13 May 2019

The present study is an attempt to understand the antiquity of the preserved fluvial landforms and its response to the climate-tectonics nexus through geomorphological investigations along the Jadukata, Umpung, Umngot and Umtongoi rivers in the southern front of the Shillong plateau (SP), NE India. Sedimentological characteristics, chronological analyses and morphotectonic parameters were used to describe the spatial and temporal variability in the patterns of aggradation, landform evolution and neotectonic influences in the study. Our results indicate that valley aggradation processes occurred around the transitional zone in the southern front of the SP during the mid-late Holocene era along with a hiatus in sediment deposition after $4.3 \mathrm{ka}$. Sediment generation and aggradation is modulated by precipitation anomalies associated with the Indian Summer Monsoon (ISM) variability whereas morphometric analysis suggests that activity along the Dauki-Dapsi fault has been contributing to the uplift-related deformation. Sedimentological observation supported by optically stimulated luminescence chronology obtained on palaeoflood deposits, valley-fill fluvial terraces and alluvial fans indicate their deposition during three pluvial phases: (i) 5.3-4.3 ka, (ii) 2.4-1.0 ka and (ii) 0.7-0.3 ka. Our data indicate that valley aggradation and geomorphic processes in the southern part of SP responded to short-term changes in the ISM variability with contributions from the morphotectonic activities associated with the Dauki-Dapsi fault during the late Holocene period.

Keywords. Shillong plateau; landforms; alluvial succession; Indian summer monsoon; morphotectonics; Dapsi-Dauki fault.

\section{Introduction}

The geomorphic evolution of landforms is intimately associated with the interaction between river channels and hill slope processes (Stark and
Stark 2001). In areas influenced by tectonics, landforms are known to respond to a combination of coupled processes vis-á-vis tectonic and climatic variability (Starkel 2003). In a tectonically active orogen like the Himalaya, precipitation seems to

Supplementary material pertaining to this article is available on the Journal of Earth System Science website (http://www. ias.ac.in/Journals/Journal_of_Earth_System_Science). 
be modulated by the topography, hence erosion is considered as a cumulative expression of tectonics and climate (Beaumont et al. 2001; Hodges et al. 2001, 2004; Wobus et al. 2003). For example, it has been suggested that in the southern mountain front (SMF) which is a narrow zone in the south of the main central thrust, focused precipitation coupled with high seismicity is implicated for high erosional unloading (Beaumont et al. 2001; Hodges et al. 2001, 2004; Reiners et al. 2003; Wobus et al. 2003; Thiede et al. 2004). However, according to Burbank et al. (2003) at a time scale of $10^{5}-10^{6}$ yr, the erosion rates in the Himalayas are primarily driven by the temporal changes in the rates of crustal deformation (tectonic), hence the role of climate can be considered subsidiary.

In the Himalayas, aggradational landforms are known to respond sensitively towards climatic and tectonic forcings and hence used extensively to unravel the role of climate (cyclic process) and tectonics (steady-state process) at centennial and multi-millennial time scales (Pratt-Sitaula et al. 2004; Juyal et al. 2010; Kothyari et al. 2016; Sharma et al. 2016). For example, it has been argued that valley-wide fluvial aggradation events can be ascribed to climatic forcing whereas incision into the bedrock would represent long-term surface uplift (tectonics) (Hancock and Anderson 2002; Vandenberghe 2003; Bridgland and Westaway 2008). In the Himalayas, tectonics can be considered as a continuous process which is ongoing since its inception, albeit with varying rates whereas climate can modulate the rate of surface uplift due to focused rainfall in areas located in the vicinity of the SMF (Wobus et al. 2003). Thus, the fluvial landscape in the Himalayan orogen can be treated as a cumulative representation of the coupling between the climate and tectonic processes.

Reasonable studies pertaining to the nature and evolution of fluvial landforms from the western (Bookhagen et al. 2005, 2006; Phartiyal et al. 2005; Srivastava et al. 2013; Sharma et al. 2016) and central Himalayas (Juyal et al. 2010; Chaudhary et al. 2015; Kothyari et al. 2016) exist. Compared to this, such a study from the northeastern Himalaya is scanty (Meetei et al. 2007; Srivastava and Misra 2008; Luirei et al. 2012) and absent from the Shillong plateau (SP), NE India. Therefore, the present investigation is undertaken in one of the tectonically active and monsoon-influenced southern fronts of the SP. The SP is a unique feature on the eastern arm of the Himalayan arc (located between $26^{\circ} 00^{\prime} 44^{\prime \prime} \mathrm{N}, 90^{\circ} 11^{\prime} 16.35^{\prime \prime} \mathrm{E}$ and $25^{\circ} 03^{\prime} 03.26^{\prime \prime} \mathrm{N}, 92^{\circ} 25^{\prime} 56.58^{\prime \prime} \mathrm{E}$ ) and is considered as a detached block of peninsular India as it represents a subducted wedge in front of the southvergent eastern Himalayan thrust belt and the west-vergent Indo-Burman ranges (Evans 1964; Nandy and Dasgupta 1991). SP is located on the trajectory of the Indian summer monsoon (ISM) (Bookhagen et al. 2005; Grujic et al. 2006; Sato 2013) and is bounded by the E-W Dauki fault (DF) in the south, NW-SE Dapsi thrust (DT) in the southwest, the Oldham/Brahmaputra fault in the north, the NW-SE Kopili fault and NS Jamuna fault to the west (figure 1a) (Kayal and De 1991; Nandy and Dasgupta 1991; Bilham and England 2001; Rajendran et al. 2004; Islam et al. 2011). Considering the complex tectonics and the strong ISM variability, it can be assumed that the landforms and the alluvial succession in the SP can help in enhancing our understanding of the role of coupled processes (climate and tectonics) in the evolution of landforms from the northeastern part of India. The objectives of the study are therefore to: (i) appraise the preserved alluvial successions in understanding the role of the climate-tectonics interaction; (ii) ascertain the morphotectonics status of the selected river basins and the role of local and regional structures on the morphology of the preserved landforms and (iii) reconstruct the pattern of climate variability and develop an event stratigraphy of the present study area.

\subsection{Study area}

The present study focuses on four south draining rivers (from west to east: Jadukata, Umpung, Umngot and Umtongoi) flowing towards the southern front of the SP, in the foothill of the eastern Himalaya (figure 1b) for which virtually no study exists on the pattern/nature of alluvial sequence and its evolutionary history. These south draining rivers originate from the central part of the SP and drain into the northern Bangladesh alluvial plain which is located to the immediate south of the SP (figure 1b). In the central hilly upland, the rivers are confined and have incised deep valleys on bedrock topography and are devoid of any appreciable alluvial succession. However, as the rivers emerge into the low-lying southern margin of the SP, they become unconfined, consisting of multiple tributary channels filled with gravels and sand. The above-mentioned rivers flow mainly through the 


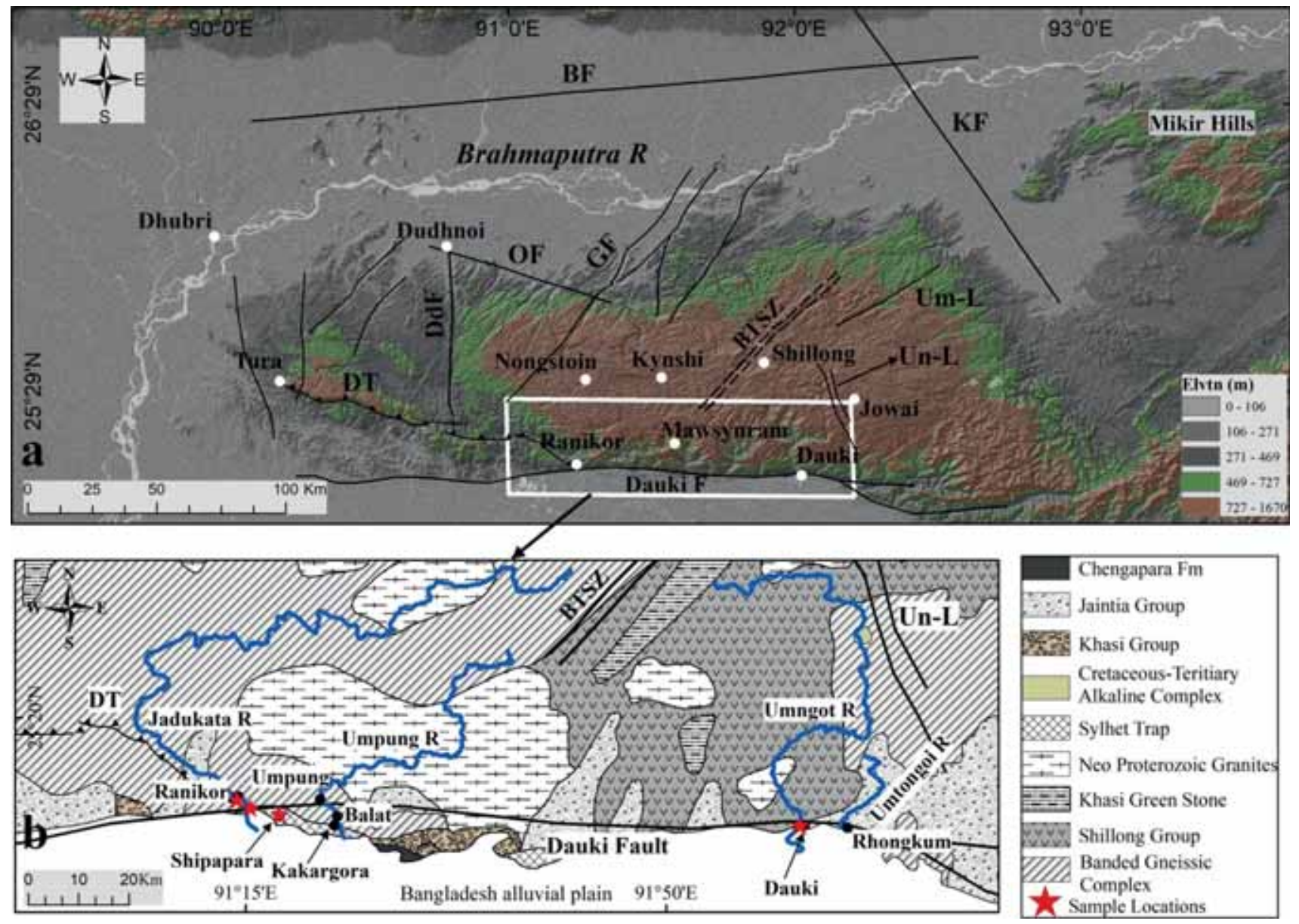

Figure 1. (a) Shaded Relief map of Shillong Plateau bounded by the Brahmaputra plains in the north and Bangladesh plains in the south. BF: Brahmaputra Fault, OF: Oldham Fault, DdF: Dhudnoi Fault, GF: Guwahati Fault, KF: Kopili Fault, BTSZ: Badapani Tyrsad Shear Zone, Un-L: Umngot Lineament, Um-L: Umkhen Lineament, DT: Dapsi Thrust, Dauki Fault. Map sources (Biswas and Greasemann 2005; Islam et al. 2011; An et al. 2010). (b) Location of Jadukata, Umpung, Umngot and Umtongoi rivers along with lithology of the area. OSL sample locations (stars).

Precambrian banded gneissic complex, Proterozoic granites, Meso-Proterozoic metasediments and Cretaceous Tertiary sediments (GSI 2009) before entering the alluvial plains of Bangladesh. The tectonically active SP (Kayal 1987; Nandy and Dasgupta 1991) is an uncharacteristic uplifted block in the foreland of the eastern Himalayas which perturbs the regional distribution of monsoonal precipitations by forming an orographic barrier to the moisture-bearing winds from the Bay of Bengal in the south (Bookhagen et al. 2005; Grujic et al. 2006).

\subsection{Geology and tectonics}

The SP is an old cratonic block which is dominantly composed of rocks of the Precambrian Age and is separated from the Surma valley (Bangladesh) by a faulted monocline with southerly dips (Evans 1964). The plateau is bounded and dissected by numerous $\mathrm{E}-\mathrm{W}, \mathrm{N}-\mathrm{S}$, NE-SW and NW-SE trending structures considered to have been formed in the course of the Kerguelen plume-related domal up-arching during the Mesozoic period (Gupta and Sen 1988; Chatterjee et al. 2007) and the uplift related to the collision of the Indian and Tibetan plates during the Cenozoic Era (Verma et al. 1976; Seeber and Armbruster 1981; Chatterjee et al. 2007). The Proterozoic meta-sedimentary Shillong group and the basement gneissic complex constitute most parts of the plateau (Dasgupta and Biswas 2000; Ghosh et al. 2005). The southern part of the plateau is overlaid by Cretaceous Sylhet basalt and Tertiary shelf sediments and in the south Khasi hills area granite plutons cut across the Shillong metasediments and the gneissic complex (Ghosh et al. 2005). 


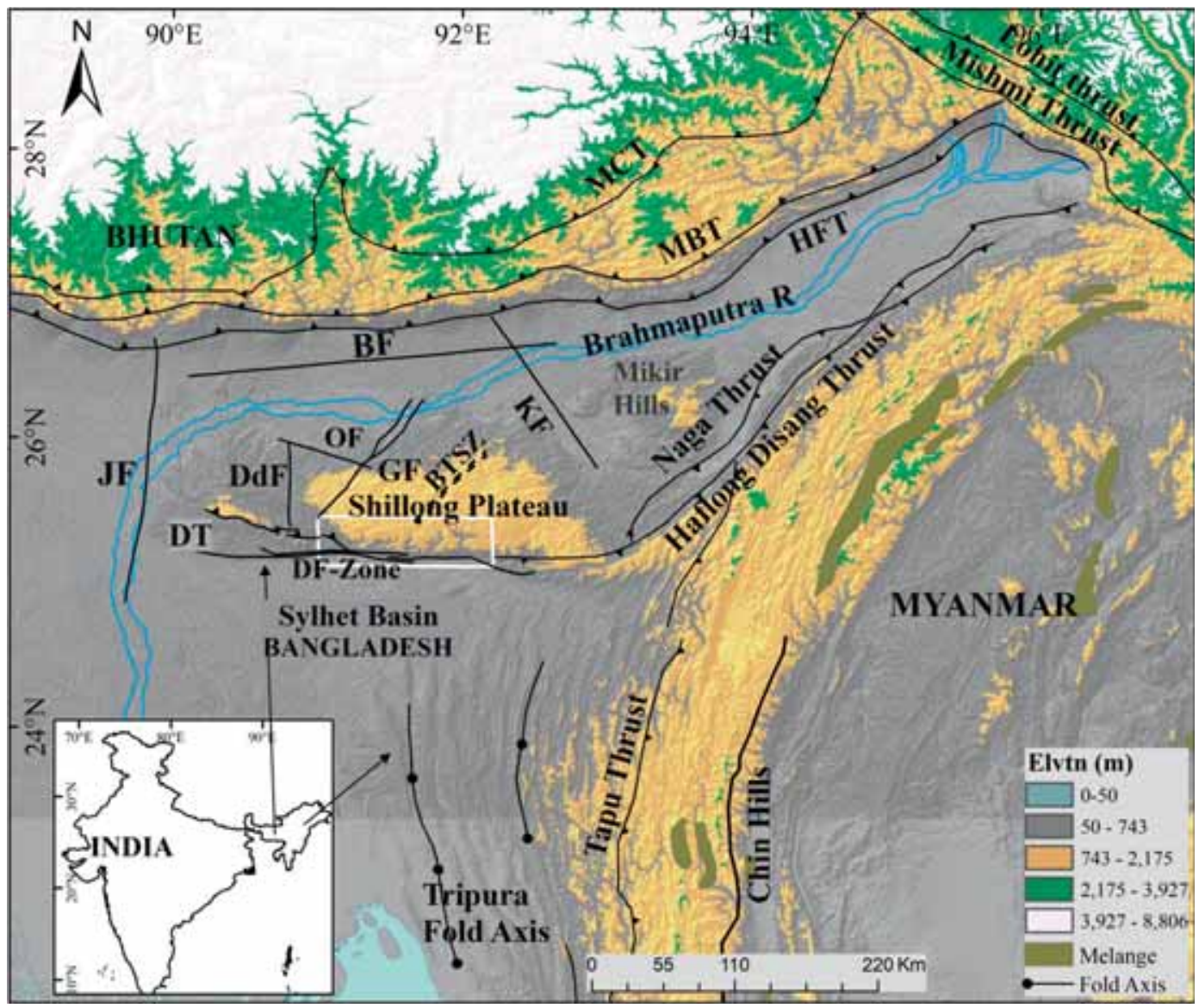

Figure 2. Regional tectonic settings of Northeast and Shillong Plateau. MCT: Main Central Thrust, MBT: Main Boundary Thrust, HFT: Himalaya Frontal Thrust, BF: Brahmaputra Fault, JF: Jamuna Fault, KF: Kopili Fault, OF: Oldham Fault, DdF: Dhudnoi Fault, DT: Dapsi Thrust, GF: Guwahati Fault, BTSZ: Badapani Tyrsad Shear Zone, DF: Dauki Fault (for sources of tectonic structure see references cited in figure 1 caption).

A number of prominent faults delineate the SP, study through aerodynamic data in the SP indicates presence of many major discontinuities representing faults, fractures and shears (Sharma et al. 2012). The $\mathrm{E}-\mathrm{W}$ trending $\mathrm{DF}$ which runs along the border between the SP and the Sylhet basin of Bangladesh marks as a spectacular topographic discordance in the region which according to Evans (1964) is a faulted monocline with a southerly dip. The DF is horizontally displaced for $\sim 250 \mathrm{~km}$ and has been considered responsible for the detachment of the SP from the Indian shield during the late Tertiary period (Evans 1964). In addition to this, the DT in the southwestern part of SP which is a tectonic boundary that separates the Archaean banded gneissic complex to the north and the tertiary metasediments to the south is considered as the western extension of the DF (Kayal and De 1991). The Brahmaputra river on the other hand separates the SP from the Himalayan front to the north, and the $\mathrm{E}-\mathrm{W}$ segment of the river at the northern boundary of the SP is named the Brahmaputra river fault (Nandy 2001; Rajendran et al. 2004). Whereas, the nearly 300-400 km long NW-SE trending Kopili fault separates the SP from the Mikir hills in the east, the Mikir massif is a part of the Shillong massif which moved northeast (Nandy 2001) (figure 2).

Many significant earthquakes have occurred in this region of which the great 1897 earthquake is the greatest (Oldham 1899). At present, the seismic activity in the SP is considered to be influenced by the collisional tectonics between the HimalayaTibet to the north and Burmese arc subduction tectonics to the east. However, the activity is not directly associated with the Himalayan seismic belt rather mostly the earthquakes are caused by active local faults (Seeber and Armbruster 1981; Kayal et al. 2006). 


\section{Materials and methods}

\subsection{Analysis and chronology of alluvial successions}

Discrete alluvial sequences preserved in the study area are investigated using conventional field characteristics, morphology, sedimentological and textural attributes in order to discern the processes and depositional environment. Three major alluvial sequences are identified which are (i) debris flow deposits, (ii) alluvial fans (AFs) and (iii) valley-fill terrace deposits. In addition to this, conspicuous linear valleys that are preserved along the southern pediment zone of the SP are mapped in order to understand their genesis. Towards this end, we used remote sensing data to map their pattern and field geomorphology supported by sedimentology.

Linear valleys are usually considered as geomorphic expressions of strike-slip faults. These valleys develop when structural blocks slip past each other in the process; a linear trough is created along the principal displacement zone due to the presence of easily erodible material along the fault zone (Burbank and Anderson 2001). Thus, the presence of a linear valley can be interpreted as the activity along the pre-existing tectonic structure. Numerical modelling suggests that a simple deflection of streams across strike-slip faults can create linear valleys along the fault trace even in the absence of any 'softening' due to brecciation (Braun and Sambridge 1997). In such valleys, the deflection of streams along the fault trace, offset, beheaded or deflected valleys and streams, offset ridges, sag ponds and shutter ridges can be observed (Burbank and Anderson 2001; Goudie 2004). One such linear valley can be observed between Shipapara and Balat in the southern front of SP, which has been discussed in detail in section 3.1.5.

The chronology of the alluvial sequences relied upon an optically stimulated luminescence (OSL) dating method using quartz mineral extract. Samples from freshly exposed sections were collected in specially designed opaque aluminium pipes (Chandel et al. 2006) and were treated with 10\% HCL and $30 \% \mathrm{H}_{2} \mathrm{O}_{2}$ to remove carbonate and organic materials. A detailed discussion on the measurement protocol and dose rate estimation can be found in Juyal et al. (2003) and Sharma et al. (2016). The luminescence measurements were obtained using an automated Ris $\varnothing$ TL-OSL reader (TL/OSLDA-20; Bøtter-Jensen et al. 2010). The elemental concentrations of uranium, thorium and potassium were estimated using a high-purity germanium detector (HPGe). The errors of measurement (both systematic and statistical uncertainties) are $<5 \%$ (Shukla et al. 2002). An average water content of $10 \pm 5 \%$ was used and the cosmic dose rate was calculated using the method suggested by Prescott and Hutton (1994).

The equivalent dose is estimated using the single aliquot regeneration (SAR) technique of Murray and Wintle (2000). Only those aliquots were considered for age estimation in which the recycling ratios were within $10 \%$ of the unity. The equivalent doses $\left(D_{\mathrm{e}}\right)$ were estimated using the weight mean of the total $D_{\mathrm{e}}$ values obtained for each sample (Juyal et al. 2006). Typically, about 45 aliquots were measured for each sample, and out of these, around 11-42 aliquots met the above criteria.

\subsection{Morphometric indices}

We used 1 arc SRTM-DEM (digital elevation model) for computing the morphometric parameters such as the longitudinal profile, stream length (SL) index, $k_{\mathrm{S}}$ and the $V_{\mathrm{f}}$ ratio. Generally, an equilibrium longitudinal river profile is smooth and concave-up shape in nature (Davis 1899; Mackin 1948), whereas any deviation from the graded concave-up shape would imply disequilibrium and is attributed to tectonic uplift/rock-perturbations (Mackin 1948; Leopold and Maddock 1953). The SL gradient index is defined as $\mathrm{SL}=(\Delta H / \Delta L) L$, where $\Delta H$ is the change in elevation of the reach; $\Delta L$ is the length of the reach and $L$ is the total stream length from the source to the reach of interest (Hack 1973). The SL index is used as an expression of the stream power and responding sensitively to changes in channel gradient (Hack 1973), hence anomalously high or low SL values are used to ascertain tectonic stability/instability (Keller and Pinter 2002; Chen et al. 2003).

Channel steepness index $\left(k_{\mathrm{s}}\right)$ is widely used to determine the bedrock channel uplift (Snyder et al. 2000; Kirby and Whipple 2001; Kirby et al. 2003). The steady-state condition of a river due to erosion is balanced by the uplift in which the profile of a river acts as an inverse function of the upstream drainage area, and at the same time, the local channel gradient will decrease as a power-law function of a larger drainage area. The relationship results in a concave-up longitudinal profile. On a logarithmic scale, the drainage area and channel steepness are linearly and negatively related (Hack 1957). This relationship of the drainage area and slope 
(downstream) for the steady state is expressed as: $\boldsymbol{S}=k_{\mathrm{S}} A^{-\theta}$, where $A$ is the drainage area, $\theta$ is the concavity and $k_{\mathrm{s}}$ is the channel steepness. An increase in channel steepness can be manifested as an increase in the rock uplift rate, and/or a decrease in erosive efficiency (Snyder et al. 2000; Kirby and Whipple 2001; Kirby et al. 2003; Duvall et al. 2004). Anomalous changes in the $k_{\mathrm{s}}$ values are manifested in the form of convexities due to the differential uplift in a long profile, which are representations of localised thrusts. Experimentally determined concavity $(\theta)$ values typically range between 0.35 and 0.6 (Snyder et al. 2000; Kirby and Whipple 2001; Roe et al. 2002), considering which we used an intermediate value of normalised concavity $\theta=0.45$, suggested by Snyder et al. (2000) and Wobus et al. (2003) which is considered to be the regional mean of observed concavity values and thus the steepness value in the present study is expressed as $k_{\mathrm{sn}}$.

The ratio of the river valley floor width to valley height $\left(V_{\mathrm{f}}\right)$ is measured to differentiate between U-shaped broad-floored, mature and less tectonically active to $\mathrm{V}$-shaped valleys that indicate relatively active streams (Bull 1977; Bull and McFadden 1977; Keller and Pinter 2002). Valley width-to-height ratio $\left(V_{\mathrm{f}}\right)$ is expressed as: $V_{\mathrm{f}}=$ $2 V_{\mathrm{fw}} /\left[\left(E_{\mathrm{ld}}-E_{\mathrm{sc}}\right)+\left(E_{\mathrm{rd}}-E_{\mathrm{sc}}\right)\right]$, where, $V_{\mathrm{f}}$ is the valley-floor width to height ratio, $V_{\mathrm{fw}}$ is the width of the valley floor, $E_{\mathrm{ld}}$ and $E_{\mathrm{rd}}$ are elevations of the left and right valley divides and $E_{\mathrm{sc}}$ is the elevation of the valley floor.

\section{Results}

\subsection{Morphology and sediment assemblages of alluvial sequences}

\subsubsection{Debris flow deposits}

Due to thick canopy covers, the debris flow exposures are limited and confined to the southern fringe of the SP and are preserved in the transitional zone between the rocky upland of the southern SP and the alluvial plain of Bangladesh. The debris flow deposits are investigated at two locations, viz., along the left bank of the Jadukata river in Ranikor and near Kakargora village in the Umpung river valley. The Jadukata river incises an $\sim 100 \mathrm{~m}$ deep bedrock gorge before it debouches into the southern alluvial plain of Bangladesh (figure $3 \mathrm{a})$. Here it is worth mentioning that the river follows the tectonically active NW-SE trending DT which is the western counterpart of the DF (Kayal 1987). The influence of DT is geomorphologically expressed by an $\sim 700 \mathrm{~m}$ eastward deflection of the Jadukata river (figure $3 \mathrm{~b}$ ).

Ranikor $\left(25^{\circ} 13.275^{\prime} \mathrm{N} ; 91^{\circ} 14.231^{\prime} \mathrm{E}\right)$ : At this location, debris flow deposits are exposed along the road cut on the way to Jadukata bridge (figure 3b and c). The sediment texture is dominated by chaotic assemblages of angular sandstone lithoclasts embedded in a sandy and gritty matrix. There is no preferred orientation observed as also the fine matrix shows very poor organisation indicating very weak aqueous activity during the deposition of the debris flow (figure 3c). At places the sizes of lithoclasts are found to be $>4 \mathrm{~m}$ along the long axis.

Kakargora $\left(25^{\circ} 11.044^{\prime} \mathrm{N} ; \quad 91^{\circ} 22.051^{\prime} \mathrm{E}\right)$ : The debris flow deposits cut across (or spill over) the WNW-SES trending linear ridge scarp (figure $4 \mathrm{a}$ ). The incised debris flow shows a lower 1.7$\mathrm{m}$ thick ferruginised, matrix-supported, indurate coarse-gritty sand which is overlain by $1.3-\mathrm{m}$ thick, matrix-supported moderately compact boulders and gravels. The textural attributes suggest that the lower coarse-gritty sand was deposited under a fluvial regime (probably representing the relict terrace sand) that was subsequently buried under a debris flow event (figure 4b), probably representing an older debris flow event whereas the upper boulder dominated unit seems to be a younger event.

The southern front of the SP is dominated by steep slopes along its southern termination. Morphologically, the southern slopes (e.g., in Ranikor) can be divided into two parts: (i) a near vertical northern scarp face $\left(\sim 70-80^{\circ}\right)$ which is devoid of regolith, with scanty vegetation and the (ii) relatively gentler southern slopes $\left(\sim 20-30^{\circ}\right)$ dominated by the debris flow covered with vegetation (figure 4c). Considering that the slopes are dominated by fractured and fissile sandstone implying that the slopes were not sediment limited, hence it can be suggested that the debris flow deposits were transported from the oversteepened south facing scarp (developing the broken hill, figure 4c) under the influence of gravity aided by extreme rainfall events.

\subsubsection{Palaeoflood (PF) deposits}

In the present study, slack water deposits are observed at the confluence between Mokham nala and Jadukata river in Ranikor village in the SMF 


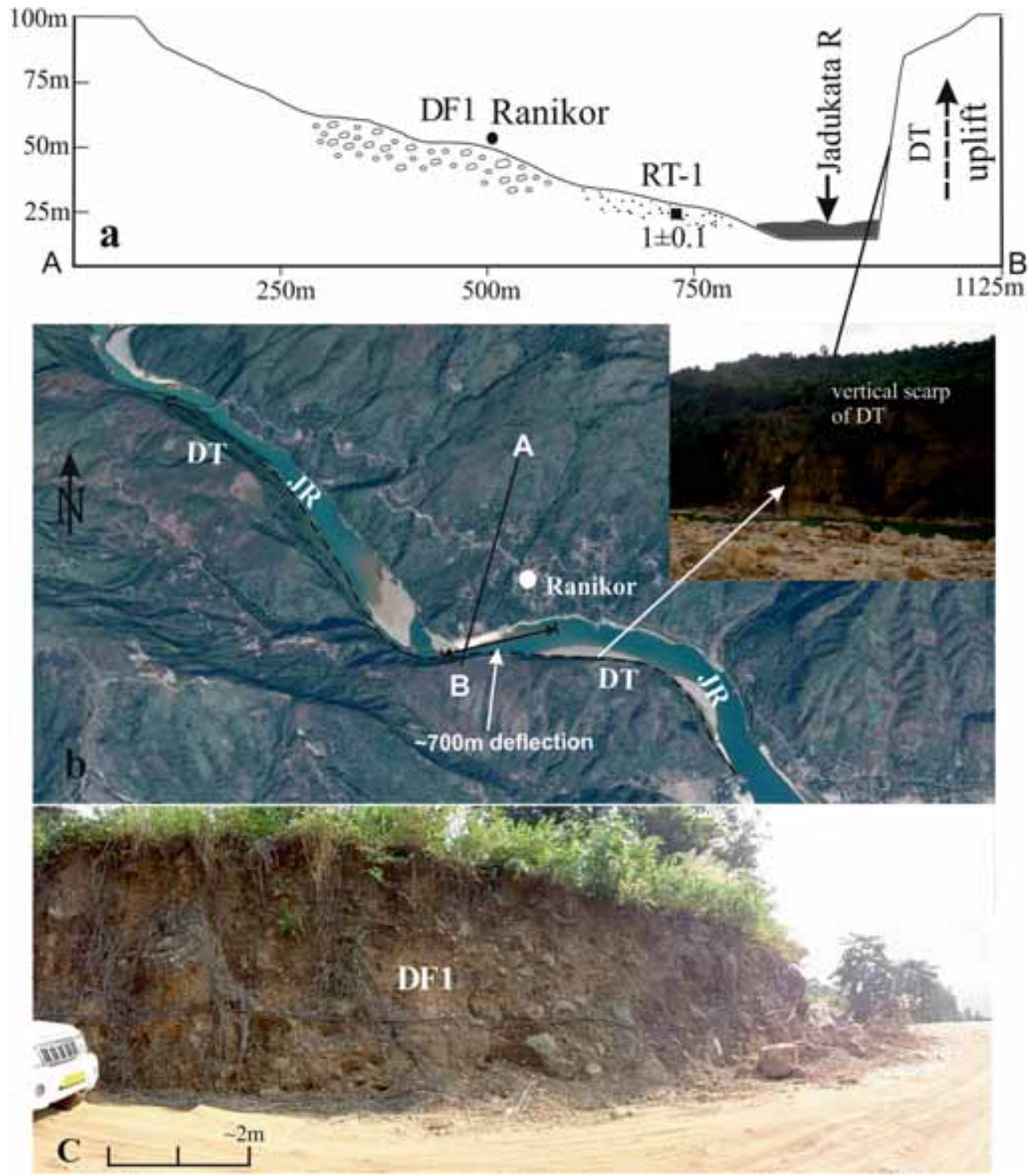

Figure 3. (a) Location of the debris flow fan (DF1) from the southern scarp of SP on the east of Ranikor, the location of the profile drawn is shown in (b). (b) 700 m eastward deflection of Jadukata river due to the activity of Dapsi Thrust (DT) near Ranikor village, inset field photograph is the vertical scarp of DT. (c) Field photograph of DF1 along the road cut, the textural attributes indicate clast dominated angular lithoclasts indicating short-distance hyper concentrated gravity driven sediment flows.

of the SP (figure 5a). Mokham nala is a tributary stream of the Jadukata river dominated by bedrock; however, in its lower 1-km stretch, the stream flows through an alluvial tract before joining the Jadukata river, which later flows into the Sylhet basin in Bangladesh.

Stratigraphy: The sediment stratigraphy is documented at the tributary's mouth where the base of the sediment succession is unexposed. From bottom upward, the lowermost $60-\mathrm{cm}$ thick sediment layer is dominated by coarse to gritty planar cross-stratified sand. At some places, the horizon contains 1-2 $\mathrm{cm}$ thick sand traps. Cross-stratified coarse gritty sand in the channel is laterally traceable upstream in the gorge section located $\sim 1 \mathrm{~km}$ upstream from the PF sequence (figure $5 \mathrm{a}$ and $\mathrm{b}$ ). This is followed by the deposition of $\mathrm{PF}$ sediments.

Based on the fining upward characteristics of the sediment successions, $13 \mathrm{PF}$ units (PFUs) have been identified in the 5-m thick exposed section. The oldest FU-1 contains 35-cm thick, crudely convoluted, coarse to gritty sand, overlain by $10-\mathrm{cm}$ thick sand clay containing charcoal pieces. FU-2 consists of a lower $11-\mathrm{cm}$ thick coarse to medium 

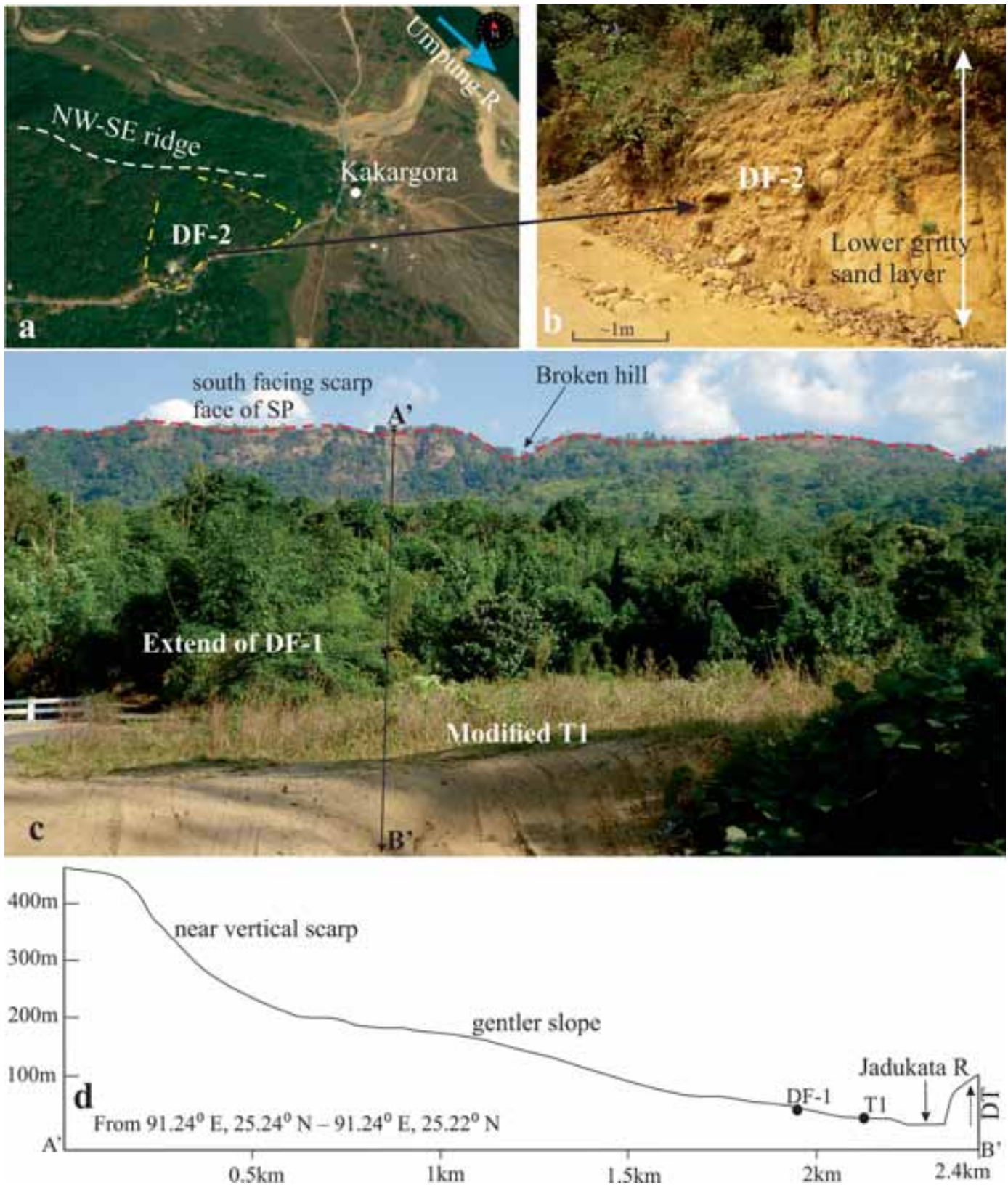

Figure 4. (a, b) Location of the Debris flow (DF2) near Kakargora, the section is observed on the way to Umpung river bear Balat. (c) Field photograph showing the near vertical slope of the south facing scarp (on the north) marked by red and the relatively gentler slope (vegetated portion) that radiates down and terminates near Jadukata river. (d) Profile showing the two different slopes observed near Ranikor on the southern slopes of SP.

sand and overlain by 4-cm thick sandy clay deposit, and the entire horizon is dispersed with charcoal. FU-3 contains a lower $10-\mathrm{cm}$ thick coarse to medium sand horizon, capped by 5 -cm thick impersistent sandy clay. FU-4 is $25-\mathrm{cm}$ thick, and the lower layers consist of coarse to medium sand followed by a 15 -cm thick silty-clay layer interspersed with ferruginous centimetre thick medium to fine sandy lenses. FU-5 contains a lower $10-\mathrm{cm}$ thick, medium to fine laminated sand, displaying a swelling and pinching character overlain by $10-\mathrm{cm}$ thick, sticky silty clay. FU-6 is 5-cm thick medium to fine sand overlain by centimetre thick laminated clay. FU-7 is 5-cm thick, parallel laminated coarse to medium ferruginous sand overlain by centimetre thick silty-clay layer. FU-8 contains $20-\mathrm{cm}$ thick, medium to fine sand and is capped by a 5 -cm thick grey to dark brown clay layer. FU-9 has 8-cm thick medium to fine sand which is capped by centimetre thick dark grey clay. FU-10 consists of $4-\mathrm{cm}$ 

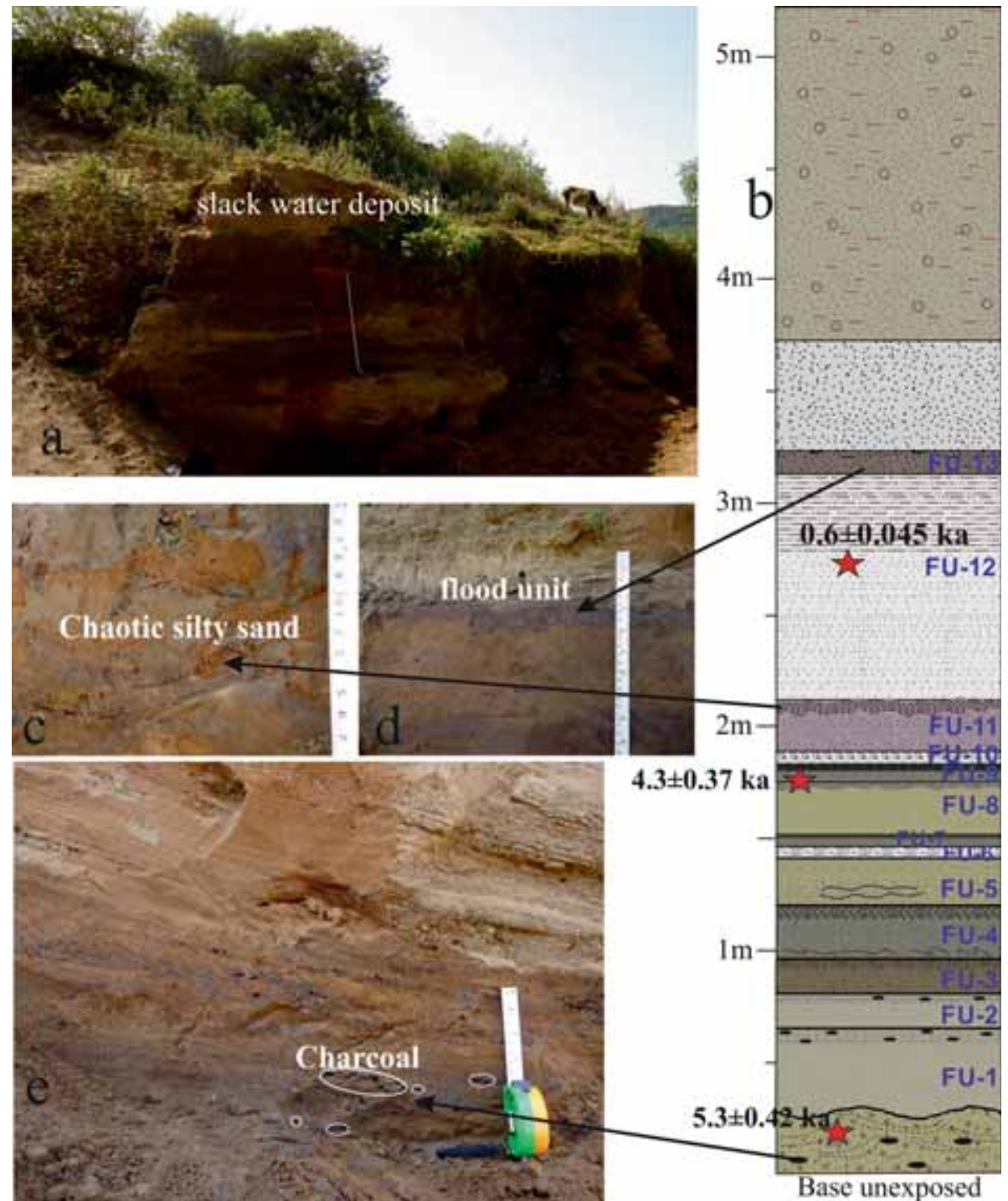

Figure 5. (a) Location of Slack water deposit in Mokham nala a tributary of the Jadukata river, (b) Stratigraphic profile of the plaeo flood unit, $(\mathbf{c}, \mathbf{d}, \mathbf{e})$ close up view of the flood units.

medium to fine sand capped by discreet silty-clay lamina. FU-11 has a 15-cm thick medium to chaotic fine sand, overlain by a 10 -cm thick silty-clay layer. The chaotic nature of the sand could be due to the turbulence in the calm water condition caused by wave or seismic action. FU-12 has 60 -cm thick well-graded medium to fine sand at the bottom, which is overlain by $40-\mathrm{cm}$ thick, moderately weathered silty sand. FU-13 has $10-\mathrm{cm}$ thick, loose coarse to medium sand capped by 5 -cm thick, weathered silty sand. The boundary between the sand and the upper silty sand is wavy. The sediment succession is finally capped by $\sim 2 \mathrm{~m}$ sand, the lower $50 \mathrm{~cm}$ consists of loose coarse to medium sand, and the upper $\sim 1.5 \mathrm{~m}$ consists of gritty to coarse crudely planar-laminated sand (figure 5b).

\subsubsection{Alluvial fans}

AFs are investigated at three locations which are proximal to the streams and are located in the transitional zone between the rocky upland of southern SP and the northern Bangladesh alluvial plain.

Umpung fan $\left(25^{\circ} 12.755^{\prime} \mathrm{N} ; 91^{\circ} 21.160^{\prime} \mathrm{E}\right)$ : The $\mathrm{AF}$ is preserved near Umpung bridge. At this location, the Umpung river emerges from the rocky upland and debouches into the southern alluvial plain (figure 6a). A WNW-ESE trending elevated ridge constricts the western part of the river whereas the eastern part is restricted by a relatively gentle $\mathrm{N}-\mathrm{S}$ trending transverse gravel ridge (figure 6a). The WNW-ESE trending ridge (on the western part) has tilted the AF towards the SE, 


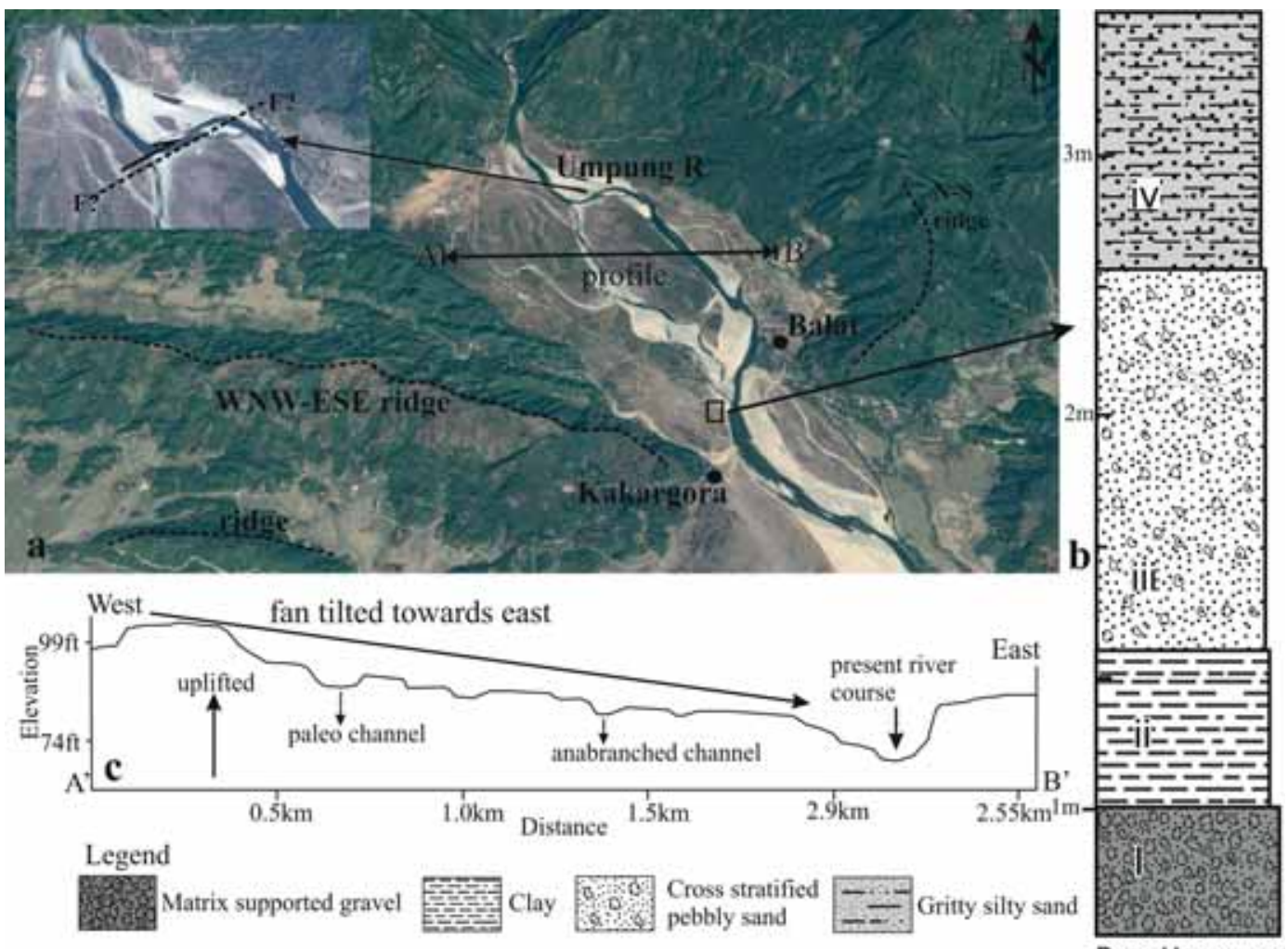

Figure 6. (a) Umpung river and associated fan near Balat $\left(25^{\circ} 11.957^{\prime} \mathrm{N}, 91^{\circ} 22.642^{\prime} \mathrm{E}\right)$ as it emerges from the mountain front, note the alluvial fan show a preferential growth towards east. (b) Detailed lithostratigraphy of the exposed alluvial fan facies on the western bank of Umpung river (location, marked by black arrow). (c) Profile drawn from west to east (marked in 'a') showing eastward tilting.

the fan is back tilted towards the NW-SE and the slope gradient of the fan is $\sim 8-10^{\circ}$. Correspondingly, an E-W trending linear fault (F1?) has laterally deflected the Umpung river $\sim 360 \mathrm{~m}$ (aerial distance) towards the east around the fan head (figure 6a).

Stratigraphy: The stratigraphy of the AF exposed by the Umpung river is discussed as follows. From bottom upwards (base unexposed), the lowest horizon consists of $50-\mathrm{cm}$ thick, subrounded to rounded, moderately sorted, imbricated and matrix-supported gravel (unit-i). This is succeeded by a $60-\mathrm{cm}$ thick sticky, grey coloured clay which is moderately weathered and stands out as a laterally continuous platform (unit-ii). This is followed by145-cm thick, gritty, cross-stratified pebbly sand (unit-iii). Overlying this is $100-\mathrm{cm}$ thick moderately compact silty sand punctuated by gritty sand lenses (unit-vi) (figure 6b).

Based on the sedimentary architecture, it can be suggested that the sediment succession represents distal AF facies with frequent lateral channel migration as indicated by changing textural attributes. The facies assemblages indicate that there were two generations of AF aggradation represented by the lowermost gravel (unit-i) and the upper cross-stratified gritty sand (unitiii). The AF morphology is better preserved along the western flank compared to its eastern counterpart (figure 6a). The asymmetric morphology of the AF can be ascribed to a preferential eastward tilting (figure 6a and c) (Duarah and Phukan 2011; Imsong et al. 2016).

Umngot fan $\left(25^{\circ} 11.122^{\prime} \mathrm{N} ; 92^{\circ} 1.341^{\prime} \mathrm{E}\right)$ : Around Dauki village, the Umngot river exits from the confined SP and debouches into the southern alluvial plain (figure 7a). Based on the elevation differences, an older generation of the AF terrace and a younger generation of the fluvial terrace are discerned. The older AF terrace (D-AF) lies $\sim 10 \mathrm{~m}$ above the river bed, whereas the younger fluvial terrace (D-T1) is inset within the older D-AF and lies $\sim 5 \mathrm{~m}$ above the present river bed (figure $7 \mathrm{a}$ ) (the fluvial terrace D-T1 is discussed in section 3.1.4).

The D-AF is fluvially modified into a terrace surface and is characterised by matrix-supported, 


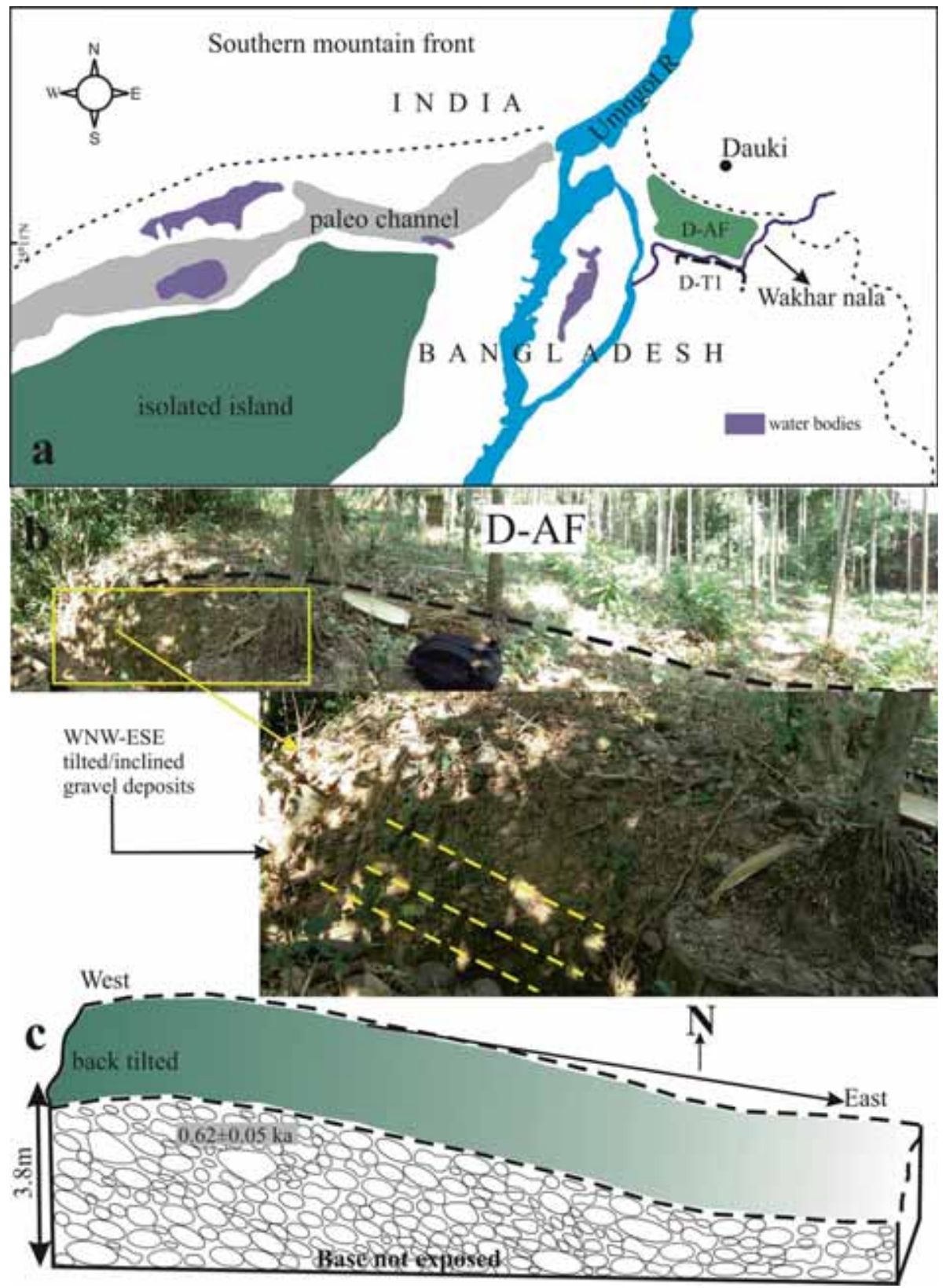

Figure 7. (a) Location of Umngot river and Dauki in the southern front of SP. (b, c) field photo and cartoon of the alluvial fan (D-AF) observed, the fan is tilted towards the east, exposing a WNW-ESE $\sim 4 \mathrm{~m}$ scarp, the fan is tilted at an angle of $\sim 5-8^{\circ}$. The exposed scarp face consists of assorted matrix supported rounded pebbles and gravels.

assorted, subrounded litho clasts. This terrace is thickly vegetated and laterally extensive towards the eastern flank (figure 7b). A remnant of $\mathrm{D}-\mathrm{AF}$ can be seen as an isolated island towards the southwest of the Bangladesh side of the border (figure 7a). The D-AF has a well-developed WNWESE scarp of $\sim 4 \mathrm{~m}$ and the surface morphology of the back tilting (towards the east) has a slope gradient of $\sim 5-8^{\circ}$. The tilted slope dies out after $\sim 50 \mathrm{~m}$ and becomes flattened (figure $7 \mathrm{c}$ ). We suggest that the tilting of the D-AF is associated with the tectonic activity and is not an artefact of the post-deposition modification by erosion for the following reasons: (i) The regional slope of the surface in the vicinity of the D-AF is towards the west as indicated by the stream flow pattern. For example, the Wakhar nala (stream) that has incised both the older AF and younger terrace flows towards the west and meets the south-flowing Umngot river at the termination of the alluvial plain (figure 7a). (ii) Compared to this, the D-AF has a slope (tilt) towards the east which is at variance 

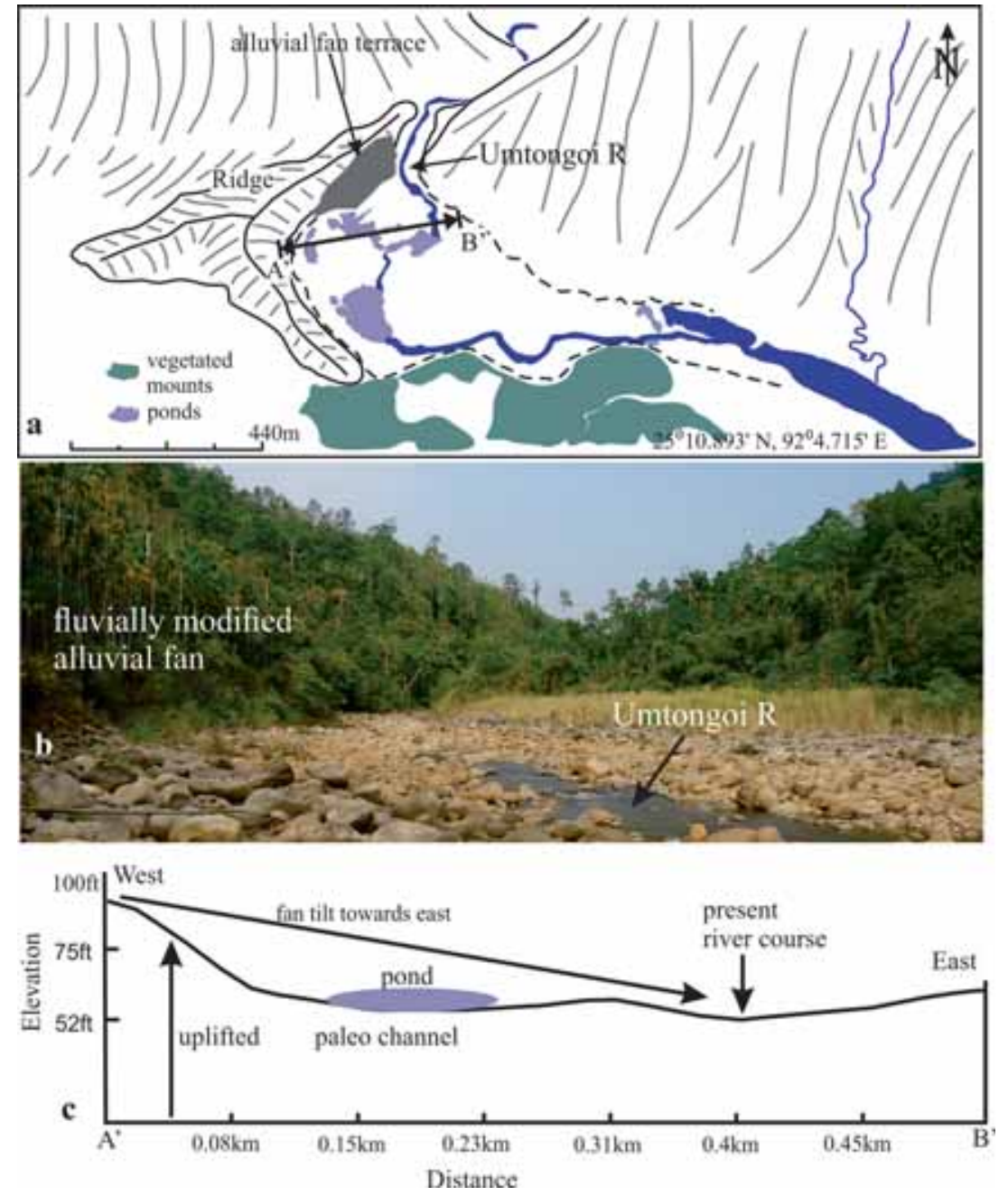

Figure 8. (a) Location of the Umtongoi river and associated fan on the southern front of SP, the fan is seen to be constricted by a ridge on its western side, and hence obstructed the river by the protrusion of the alluvial fan and is seen to have shifted the river towards east, (b) the distal part of the alluvial fan, and (c) horizontal profile drawn in the middle of the alluvial fan suggests tilting of the fan towards east with associated shifting of the river.

with the regional slope of the area implying that the back tilting of D-AF was caused by tectonic activity.

Umtongoi fan $\left(25^{\circ} 11.171^{\prime} \mathrm{N} ; 92^{\circ} 4.510^{\prime} \mathrm{E}\right)$ : The Umtongoi river emerges from the southern front of the SP and drains into the alluvial plains of Bangladesh. The river is obstructed by an E-W trending linear ridge in the downstream section (at the Bangladesh border). As the river emerges from the southern bedrock channel of the SP, a thick pile of assorted incised debris to a depth of $\sim 100 \mathrm{~m}$ can be observed. The debris gradually merges with the Bangladesh alluvial plain in the south (figure 8a and b). The lower tapered part (in the south) of the alluvial plain is fluvially modified into a terrace surface. Based on the elevation and maturity (weathering) of the Umtongoi AF, it is considered the oldest aggradation event preserved in the study area. The southward protrusion of the Umtongoi fan appears to have obstructed the river in the past along its right bank (the western part). As a consequence, the AF shows preferential tilting towards the eastern part which is against the local slope (slope deviatory) (figure 8c). The genesis of the AF (climate or tectonic) is uncertain at this stage. However, considering the poorly sorted large litho clasts of the AF facies with the poorly organised texture suggests their deposition during an extreme event which could be a combination of both torrential precipitations coupled with seismicity. Considering that the $\mathrm{AF}$ is preferentially tilted towards the east (similar to the observation made at Dauki), we speculate that tectonics played a dominant role in tilting the Umtongoi fan. 


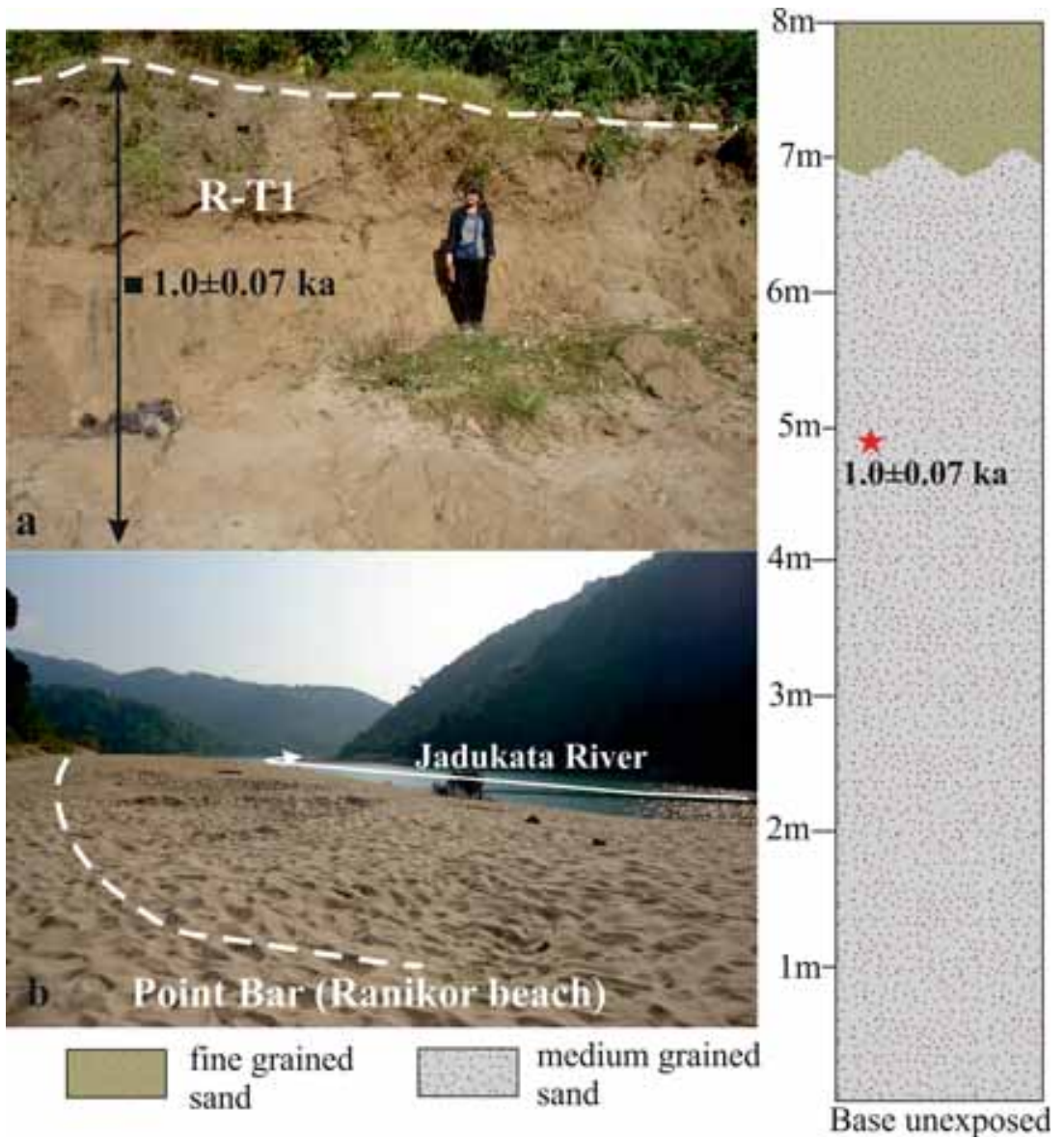

Figure 9. (a) The terrace sequence R-T1 on the left bank of Jadukata river and vertical profile of the terrace (T1). (b) The well-developed point bar observed on the left bank (concave side) of Jadukata river, it consists of fresh whitish medium to fine sand, similar textured sand can also be seen atop R-T1 at places.

\subsubsection{Fluvial terraces}

Unlike the occurrences of spectacular terrace sequences in the glacial fed Himalayan rivers (Juyal et al. 2010; Ray and Srivastava 2010; Dutta et al. 2012; Sharma et al. 2016), fluvial terraces in the southern margin of the SP are limited in extent and are poorly developed. One of the reasons could be an abrupt change in the relief from the high topography of the southern SP to the lowlying alluvial plain. Rivers debouching from the mountains to the alluvial plain shed their load due to the monotonously flat relief that decreases the stream power hence instead of the river incising through its sediments, it tends to become an anabranching/anastomosing type of fluvial system. Furthermore, due to high rainfall, the sediment residence time in the transitional zone (between the rocky upland and southern alluvial plain) is significantly low as the sediments being continuously bypassed into the southern lower reaches of the Bangladesh alluvial plain.
With these limitations, the terrain was investigated for terraced fluvial sequences particularly in the transitional zone in order to ascertain the pattern of deposition and their climatic and tectonic significance. Three localities provided a relatively good exposure of the fluvial terrace sequence, i.e.: (i) Ranikor; (ii) Shipaphara and (iii) Dauki, and the terraces investigated are as follows:

Ranikor $\left(25^{\circ} 13.324^{\prime} \mathrm{N} ; 9^{\circ} 14.450^{\prime} \mathrm{E}\right)$ : Around Ranikor, fluvial terraces are preferentially preserved along the southern flank of the Jadukata river in the transitional zone between the upper bedrock and the lower alluvial plain. A single terrace surface (R-T1) of $\sim 8.5 \mathrm{~m}$ in height (at places) is observed a few metres above the river bed (figure 9a) along the vertical section of the terrace displaying light brown, medium to fine grained sand interspersed with occasional silty-clay layers. The sediment succession of the terrace shows moderate weathering, particularly in the upper part of the terrace sediment succession. 


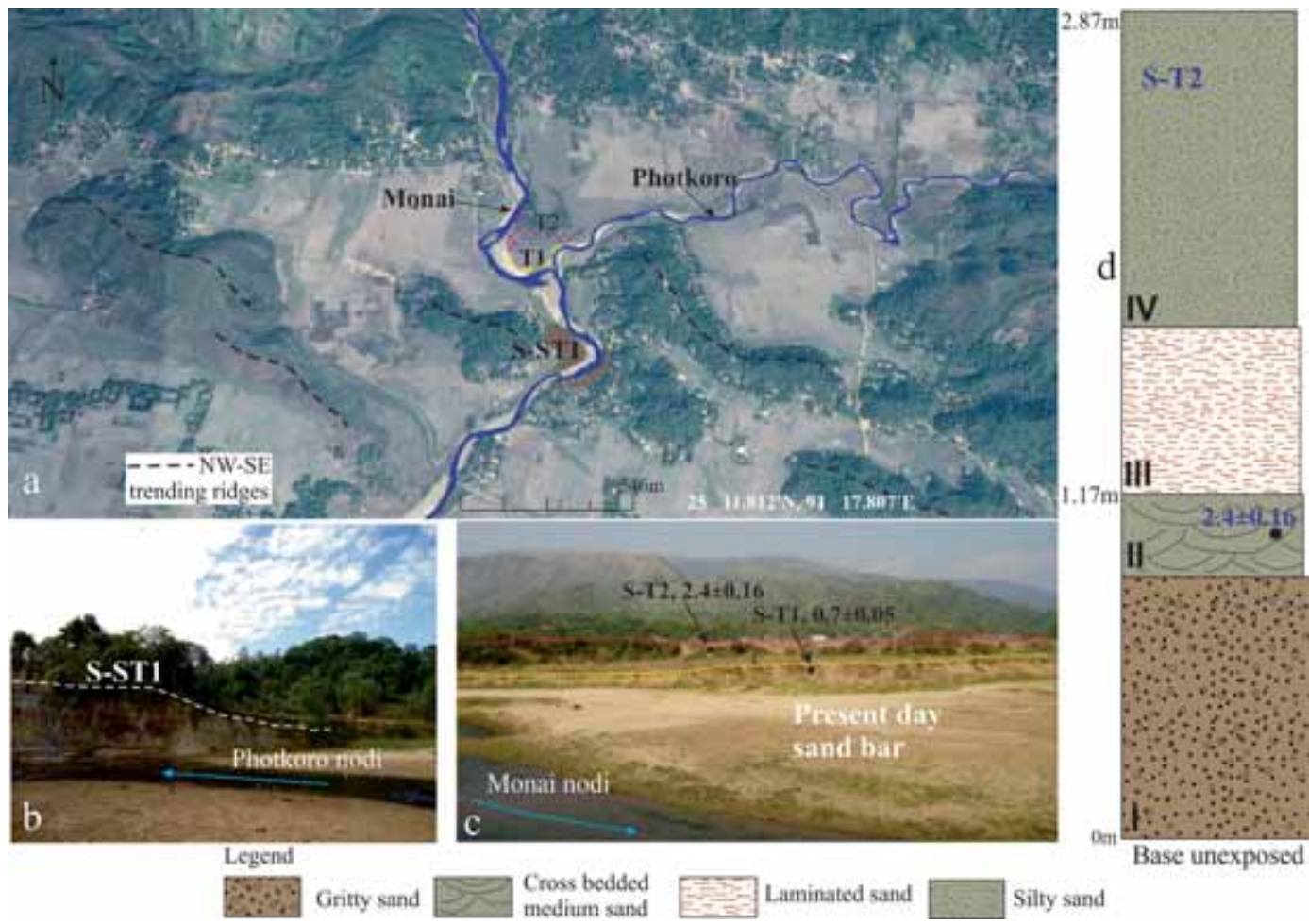

Figure 10. (a) Aerial view of the confluence of Monai and Photkoro nodi near Shipapara, (b) the concave curved strath terrace (S-ST1) downstream of the confluence of Monai and Photkoro, (c) the two flood plain terrace sequence S-T2 and $\mathrm{S}-\mathrm{T} 1$ located at the confluence of the rivers, and (d) shows the vertical section of the older terrace (S-T2) sequence.

A well-developed point bar is also observed along the meandering course (concave side) of the Jadukata river (the Ranikor beach in local parlance). The thickness of the point bar ranges between 2 and $5 \mathrm{~m}$, and the sediments are dominated by coarse to medium whitish sand (figure 9b). At few locations, the point bar is modified into the terrace surface. Similar textured sands are observed at places overlying the fluvial terrace at an elevation ranging from 5 to $10 \mathrm{~m}$, implying that the river might have experienced occasional high-magnitude floods in recent times.

Shipapara $\left(25^{\circ} 11.905^{\prime} \mathrm{N} ; 91^{\circ} 17.838^{\prime} \mathrm{E}\right)$ : This site is located at the confluence of the Monai and Photkoro streams that eventually flow towards the south into the alluvial plain of Bangladesh (figure 10a). The incision of the wide flood plain of these rivers resulted in the formation of alluvial terraces. The flood plain surface is laterally extensive both towards the east and the west. Towards the south of the confluence of the Monai and Photkoro streams, a strath terrace (S-ST1) is developed which lies marginally above the present day flood plain (figure 10a and $\mathrm{b}$ ). To the north of the confluence, two terrace surfaces, viz., S-T1 and $\mathrm{S}-\mathrm{T} 2$, representing two events of flood plain aggradations are observed (figure 10a and c).

The sediment succession in the older aggradation terrace S-T2, began with the deposition of a $90-\mathrm{cm}$ thick, ferruginous loose gritty layer (unit-i). This is overlain by a $30-\mathrm{cm}$ thick, cross-bedded, coarse to medium sand (unit-ii); following this, unit-iii consists of $60-\mathrm{cm}$ thick finely laminated silty sand, interspersed with gritty ferruginous material. This is overlain by $1.1-\mathrm{m}$ thick fine grained silty sand (unit-vi) (figure 10d). The horizon of the younger aggradation phase $\mathrm{S}-\mathrm{T} 1$ is $2.1 \mathrm{~m}$ thick and consists of medium to fine grained sand interspersed with pockets of mud.

Detailed investigation around the southern part of the flood plain terrace indicates that the sediments lying atop the dissected, highly fractured and weathered clay-rich tertiary bedrock (S-ST1) suggest that the streams once occupied a relatively large area and was flowing through the NW-SE trending linear ridge (figure 10a). Following this, with the reduction in hydrological discharge, the river sank and incised through its flood plain which eventually resulted in the occupation of the present day channel course. Geomorphic expression of the 

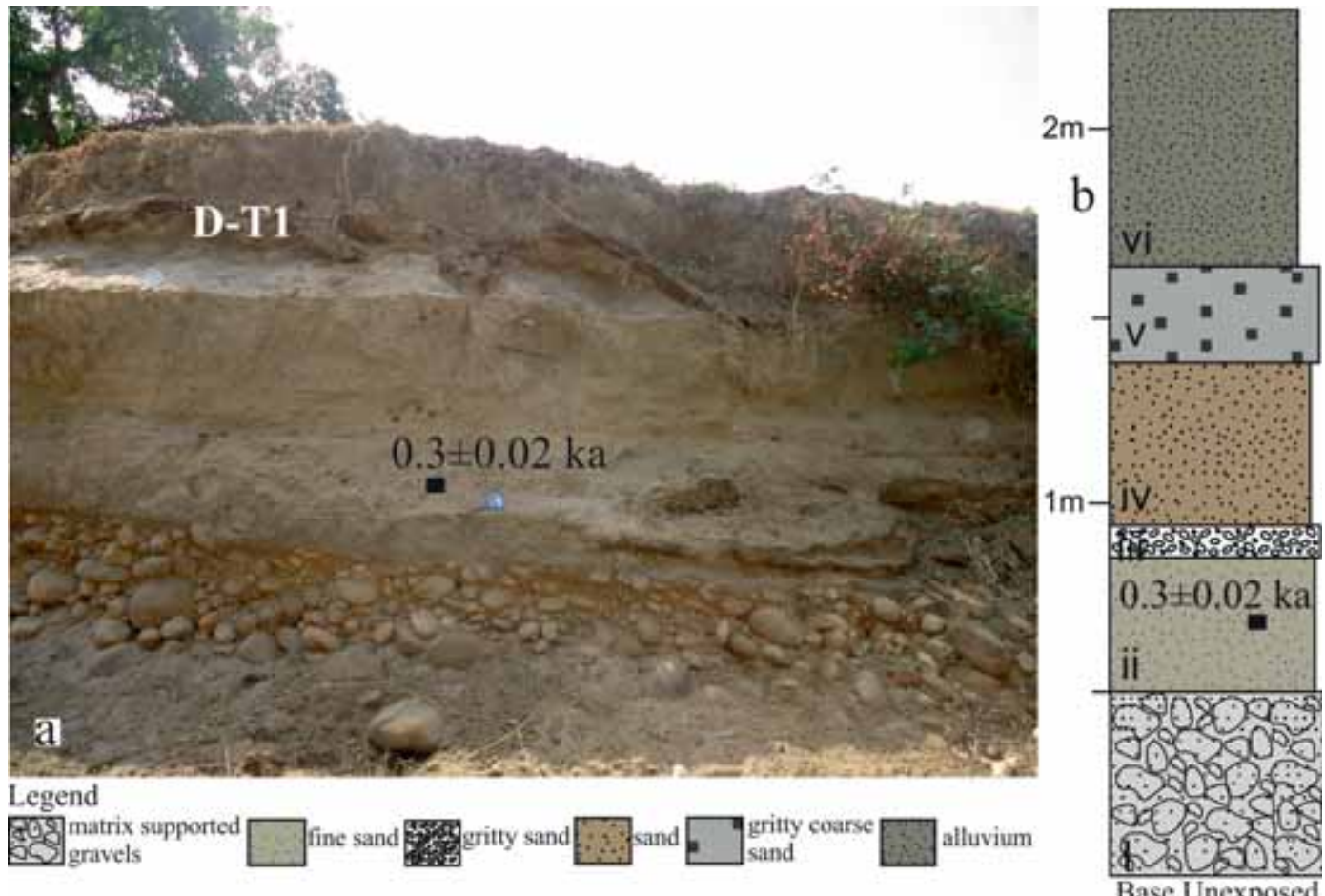

Figure 11. (a) The exposed section of the younger terrace (D-T1) observed in Dauki which has been incised by a small stream called Wakhar nala (see figure 7a). (b) Lithostratigraphic profile of the vertical section of D-T1.

confinement of the channel to the present day course is evidenced by the incision of the highly fractured and weathered bedrock on the right bank of the river. Here, the surface of the weathered bedrock is arc (convex) in shape which is overlain by variable thickness of flood plain sediments (figure 10b). Thus the sediment atop the weathered rock cannot be used to estimate the bedrock incision/uplift rate, instead the age would tell us the time of the climatically governed change in the hydrological regime.

Dauki $\left(25^{\circ} 11.148^{\prime} \mathrm{N} ; 92^{\circ} 1.197^{\prime} \mathrm{E}\right)$ : The exposed fluvial terrace (D-T1) consists of fresh-looking rounded to subrounded clast supported gravels in the lower part. This is overlain by a $50-100 \mathrm{~cm}$ thick, moderately weathered sand horizon. The terrace surface (figure 11a) is located proximal to the Umngot river (figure 7a). The stratigraphy of the sedimentary succession exposed by a transverse E$\mathrm{W}$ flowing Wakhar nala (stream) is discussed as follows.

Stratigraphy (D-T1): From bottom upwards (base unexposed), the lowermost unit consists of a 50-cm thick matrix supporting angular to subrounded pebbles and boulders (unit-i). This is overlain by $35-\mathrm{cm}$ thick, fine grained sand (unit-ii), which is succeeded by an $\sim 10$-cm thick, gritty sand layer (unit-iii). Following this, unit-vi consists of $40-\mathrm{cm}$ thick, fine grained sand which in turn is overlain by a $25-\mathrm{cm}$ thick, gritty coarse grained sand layer. The uppermost horizon is an $\sim 70$-cm thick mixture of sandy pedogenised layer (figure 11a and $b)$.

\subsubsection{Linear valleys}

The linear valleys are observed between Shipaphara and Balat $\left(25^{\circ} 11.362^{\prime}\right.$ and $\left.91^{\circ} 18.684^{\prime} \mathrm{E}\right)$ where multiple $\mathrm{E}-\mathrm{W}$ trending valleys filled with Quaternary alluvium are present and are separated from the southern Bangladesh alluvial plain by prominent boulder ridges (figure 12). The valley widths are approximately $0.5-1.5 \mathrm{~km}$ and the length varies between 4 and $6.5 \mathrm{~km}$. The Quaternary alluvium is dominantly fine silty sand and clay deposits. No major river drains through these valleys except for few north-south draining streams that enter the valley from the southern escarpment of SP and drain towards the Bangladesh alluvial plain (figure 12).

The E-W trending strike-slip DF runs parallel to the linear valleys (Evans 1964; Nandy 2001). The north-south draining steams while traversing across the DF show a preferential eastward deflection suggesting the tectonically active nature 

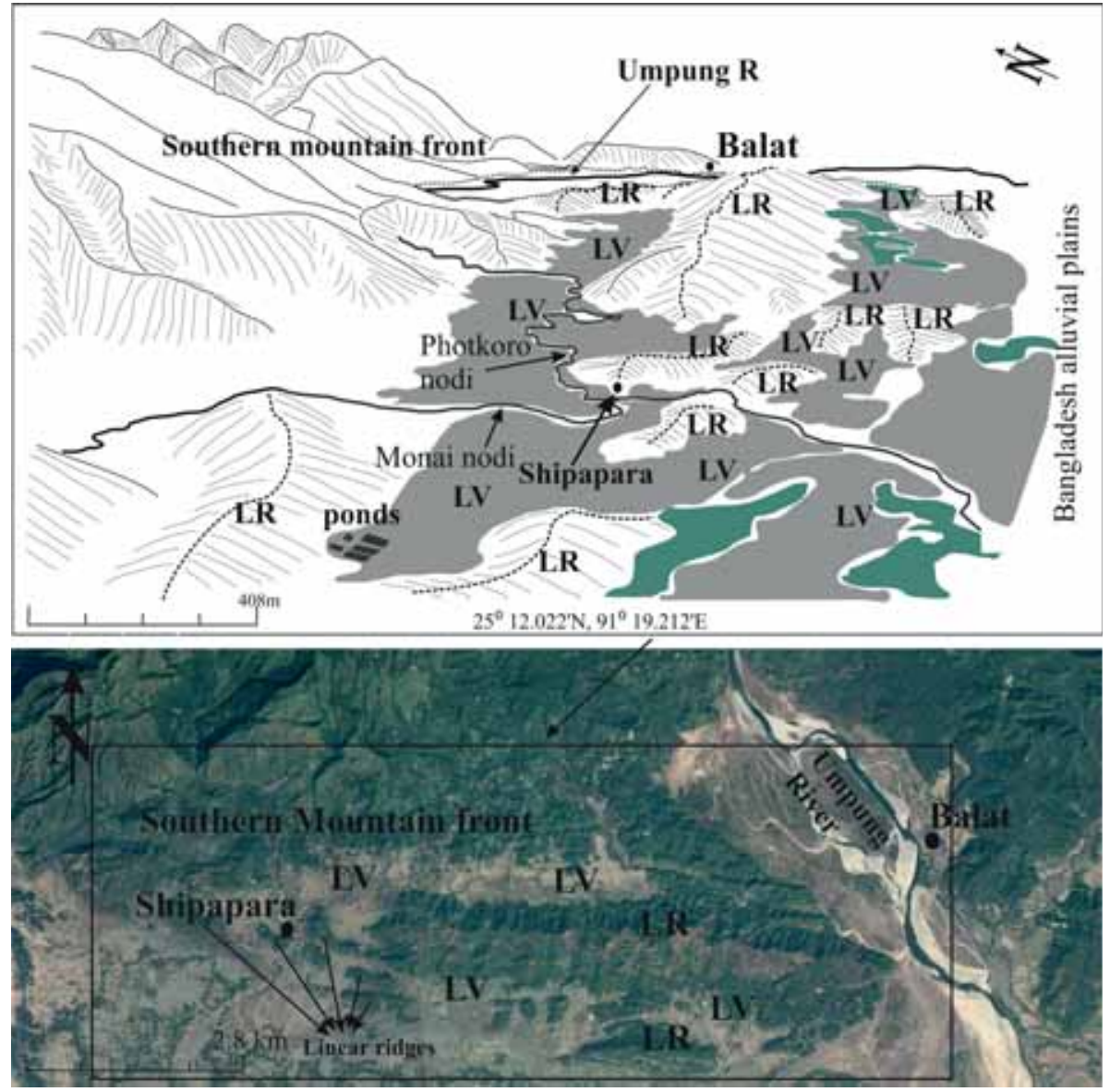

Figure 12. Linear valleys between Shipapara and Balat $\left(25^{\circ} 11.775^{\prime} \mathrm{N}, 91^{\circ} 17.820^{\prime} \mathrm{E}\right.$ and $\left.25^{\circ} 11.957^{\prime} \mathrm{N}, 91^{\circ} 22.642^{\prime} \mathrm{E}\right)$, the valleys extent about $0.5-1.5 \mathrm{~km}$ in width at different places. LR shows NW-SE trending ridges delimiting the linear valleys (LV) observed in this area.

of the DF (Imsong et al. 2016). Based on the morphotectonic consideration (sympathetic to the DF), we tend to suggest that the linear valleys were created during the enhanced activity associated with the DF during which the development of parallel strike-slip splays in the southern front occurred. The shearing and fracturing of the lithology coupled with continued erosion finally led to their present topographic form (Cunningham and Mann 2007).

\subsection{Chronology}

Optical ages from the PF sequence investigated at Ranikor, Mokham nala are obtained for the lowermost, middle and upper sand horizons. The lowermost horizon is dated to be $5.3 \pm 0.42 \mathrm{ka}$; following this, there are a number of discreet flooding events. The middle horizon is dated to be $4.3 \pm 0.37 \mathrm{ka}$, subsequent to which, two flooding events are observed. The uppermost horizon is dated to be $0.6 \pm 0.045 \mathrm{ka}$. The valley-fill terrace
(R-T1) at Ranikor (at the bank of the Jadukata river) which is deposited by scouring off the older debris flow deposits (DF1) is dated to be $1.0 \pm$ 0.07 ka. Similarly, in Shipapara, the two levels of valley fill terraces, viz. S-T2 and S-T1, are dated between $2.4 \pm 0.16$ and $0.7 \pm 0.049 \mathrm{ka}$, respectively. The age of S-T2 (2.4 ka) gives the probable upper limit of the valley-fill aggradation event in the area. The younger fluvial terrace (D-T1) observed in Dauki is dated to be $0.3 \pm 0.02 \mathrm{ka}$. The older AF $(\mathrm{D}-\mathrm{AF})$ at Dauki is dated to be $0.6 \pm 0.05 \mathrm{ka}$ (table 1).

\subsection{Geomorphic indices}

\subsubsection{Longitudinal profile and SL gradient index}

The upstream and midstream segments are dominated by Precambrian gneissic rock, whereas the downstream segments are dominated by alluvium. The upstream segment of the Jadukata river profile shows a low SL index as it drains through 
Table 1. OSL chronology details of the sedimentary sections from WIHG Dehradun and Physical Research Laboratory, Ahmedabad, India and ${ }^{14} \mathrm{C}$ ages from Imsong et al. (2018).

\begin{tabular}{|c|c|c|c|c|c|c|c|c|}
\hline Sl. no. & Landform & $\begin{array}{c}\text { Sample } \\
\text { no. }\end{array}$ & $\mathrm{U}(\mathrm{ppm})$ & Th (ppm) & $K \%$ & $\begin{array}{c}\text { Dose rate } \\
\quad(\mathrm{Gy})\end{array}$ & $E_{\mathrm{d}}(\mathrm{Gy})$ & Age (ka) \\
\hline \multicolumn{9}{|c|}{ Ranikor } \\
\hline 1 & $\mathrm{~T} 1$ & LD-1701 & $3.06 \pm 0.15$ & $28.0 \pm 1.4$ & $2.12 \pm 0.2$ & $4.493 \pm 0.4$ & $4 \pm 0.15$ & $1.0 \pm 0.07$ \\
\hline \multicolumn{9}{|c|}{ Mokham nala } \\
\hline 2 & PF (upper) & LD-1855 & $3.73 \pm 0.19$ & $29.9 \pm 1.5$ & $2.38 \pm 0.1$ & $4.98 \pm 0.36$ & $3 \pm 0.09$ & $0.6 \pm 0.045$ \\
\hline 3 & PF (mid) & LD-1856 & $3.59 \pm 0.18$ & $27.8 \pm 1.4$ & $2.71 \pm 0.4$ & $5.14 \pm 0.37$ & $22 \pm 1.09$ & $4.3 \pm 0.37$ \\
\hline 4 & PF (lower) & LD-1857 & $3.88 \pm 0.21$ & $25.1 \pm 1.3$ & $2.2 \pm 0.11$ & $4.55 \pm 0.32$ & $24 \pm 0.95$ & $5.3 \pm 0.42$ \\
\hline \multicolumn{9}{|c|}{ Shipapara } \\
\hline 5 & $\mathrm{~T} 2$ & $\mathrm{~S} 4$ & $1.89 \pm 0.04$ & $13.5 \pm 0.2$ & $0.73 \pm 0.1$ & $2.11 \pm 0.13$ & $5 \pm 0.12$ & $2.4 \pm 0.16$ \\
\hline 6 & $\mathrm{~T} 1$ & LD-1711 & $2.63 \pm 0.13$ & $17.0 \pm 0.85$ & $1.42 \pm 0.1$ & $3.080 \pm 0.3$ & $2 \pm 0.07$ & $0.7 \pm 0.049$ \\
\hline \multicolumn{9}{|l|}{ Dauki } \\
\hline 7 & $\mathrm{AF} 2$ & LD-1712 & $4.22 \pm 0.21$ & $14.5 \pm 0.73$ & $1.82 \pm 0.2$ & $3.611 \pm 0.4$ & $2 \pm 0.08$ & $0.6 \pm 0.05$ \\
\hline 8 & AF1 & LD-1714 & $3.45 \pm 0.17$ & $20.4 \pm 1$ & $1.94 \pm 0.2$ & $3.922 \pm 0.4$ & $1 \pm 0.02$ & $0.3 \pm 0.02$ \\
\hline \multicolumn{9}{|c|}{ Chandubi Lake: radiocarbon ages (calibrated) of tree trunks (ka) from Imsong et al. (2018) } \\
\hline 9 & $0.8 \pm 0.05 \mathrm{ka}$ & & & & & & & \\
\hline 10 & $1.0 \pm 0.05 \mathrm{ka}$ & & & & & & & \\
\hline 11 & $1.8 \pm 0.08 \mathrm{ka}$ & & & & & & & \\
\hline 12 & $0.4 \pm 0.03 \mathrm{ka}$ & & & & & & & \\
\hline
\end{tabular}

T: terrace; PF: palaeo flood; AF: alluvial fan.
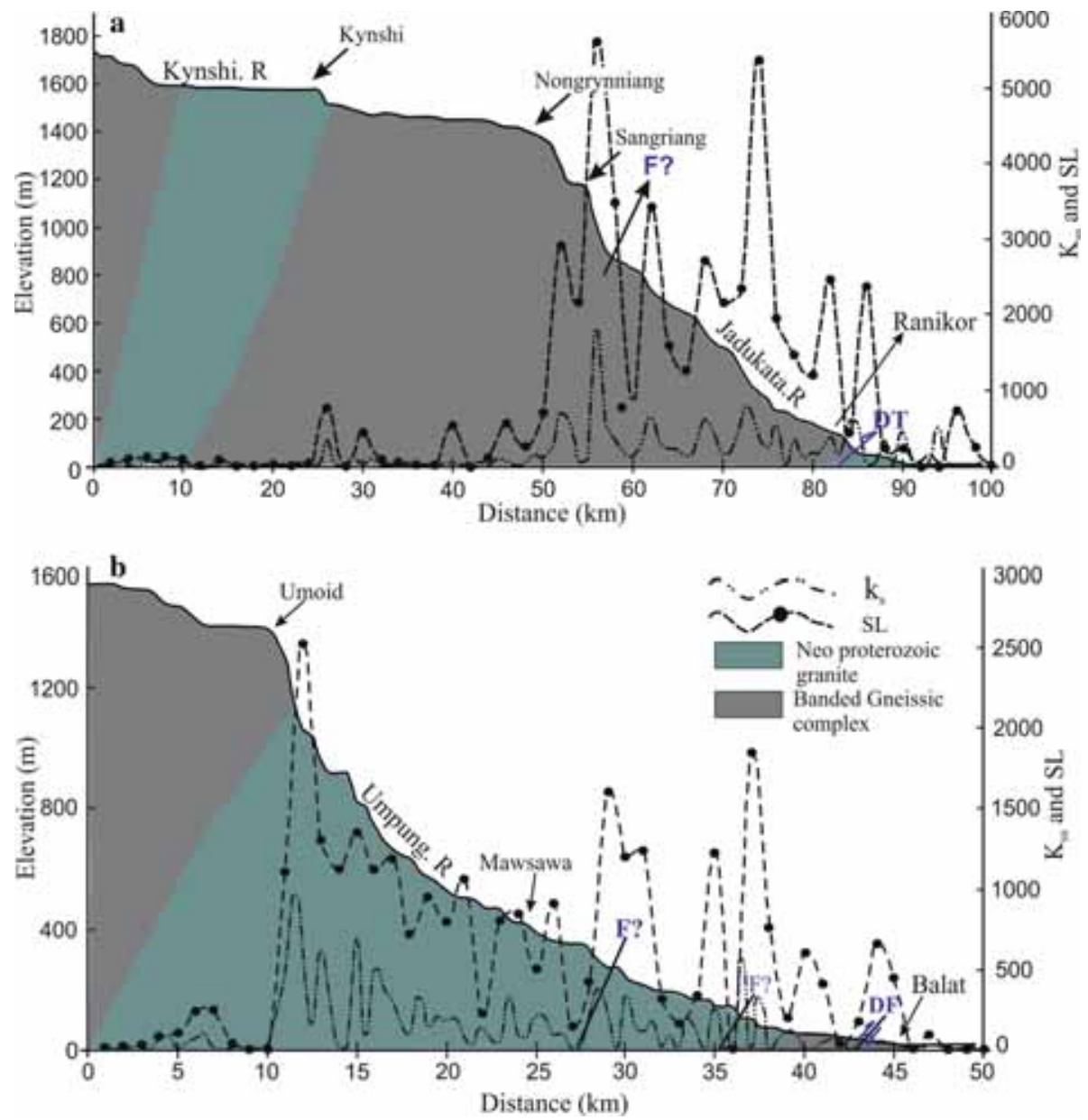

Figure 13. (a, b) Longitudinal profile drawn for Jadukata and Umpung rivers and overlaid SL and $k_{\mathrm{sn}}$ indices, DT: Dapsi thrust, DF: Dauki Fault. (c, d) Longitudinal profile drawn for Umngot and Umtongoi rivers and overlaid SL and $k_{\mathrm{sn}}$ indices, DF: Dauki Fault. 

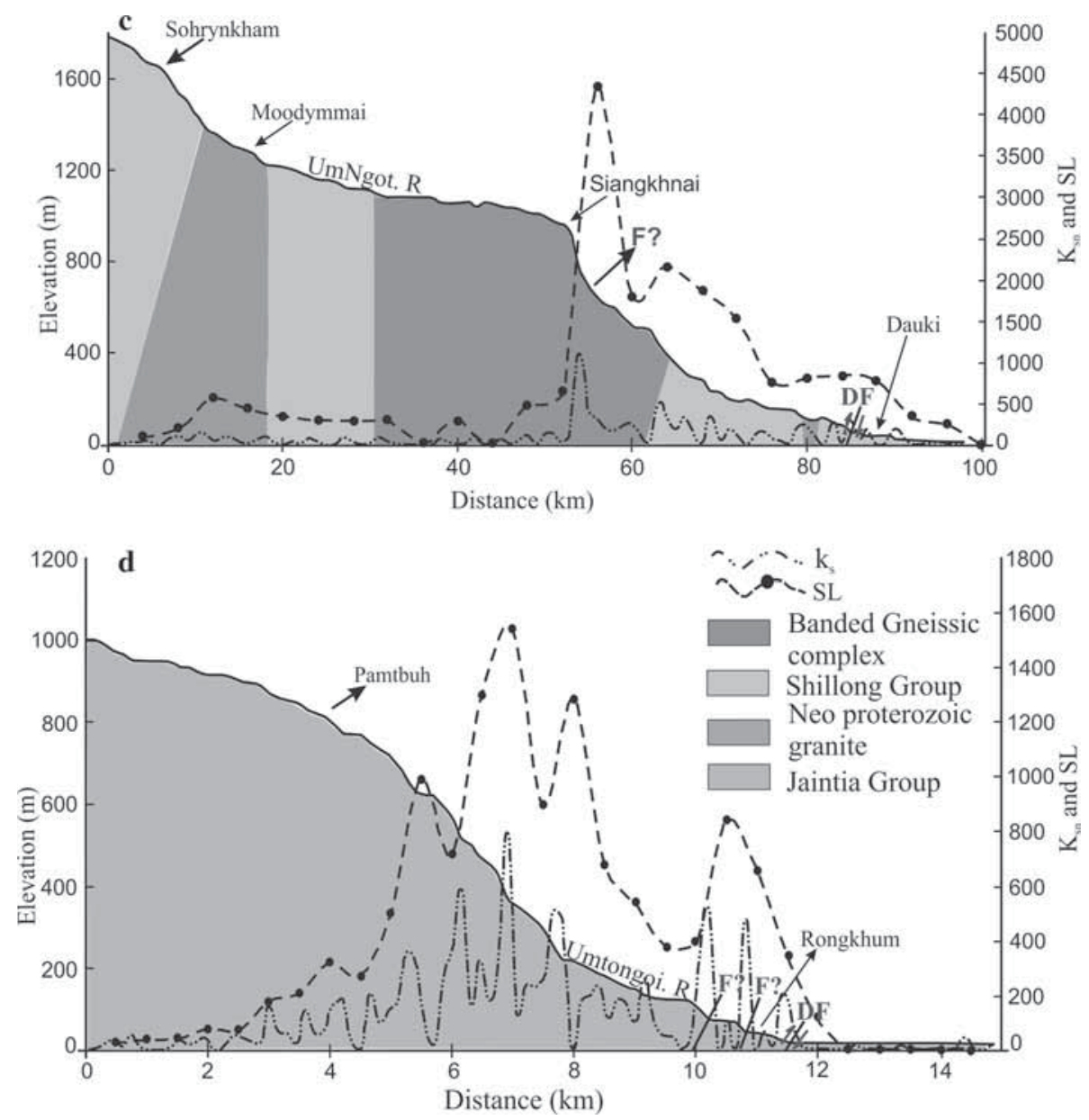

Figure 13. (Continued.)

the flat-topped plateau topography. A knick point is observed at $\sim 26 \mathrm{~km}$ below the source of this river having a high SL value (SL $=754$ ) near Kynshi (figure 13a). In the midstream segment, the number of knick points increases with correspondingly very high $\mathrm{SL}$ values $(\mathrm{SL}=5600,5365)$ at 56 and $74 \mathrm{~km}$ from the source (figure 13a). Similarly, in the downstream segment (the lower alluvial segment), two prominent very high SL values $(\mathrm{SL}=2460$ and 2365) are observed at 82 and $86 \mathrm{~km}$ away from the source. Around this location, the river traverses the DT (figure 13a).

The Umpung river displays a concave-up profile in the upstream segment, following which a major break in the longitudinal profile is seen to be associated with a knick point and a very high SL value $(\mathrm{SL}=2520)$. The longitudinal profile of the Umpung river is riddled with innumerable small-scale perturbations in the midstream and downstream segments. However, three zones of conspicuously high SL values can be found: (i) between 29 and $31 \mathrm{~km}$ away from the river source with
SL values ranging between 1595 and 1240, (ii) at $37 \mathrm{~km}$ with a very high SL value $(\mathrm{SL}=1850)$ and (iii) around $44-45 \mathrm{~km}$ with moderately high SL values $(\mathrm{SL}=660,450)$, this location lies proximal to the DF zone (figure 13b).

The Umngot river has a typical concave (graded) profile in the upstream segment until $\sim 28 \mathrm{~km}$, and as it flows down towards the midstream segment, the profile becomes convex with a noticeable knick point which is associated with a very high SL peak $(\mathrm{SL}=4340)$ (figure 13c). Further downstream, two zones of very high SL values are observed, one between 64 and $72 \mathrm{~km}$ away from the source with $\mathrm{SL}=2160-1600$ and between 84 and $88 \mathrm{~km}$ (away from the source) having a high SL value = 840-770. The (latter) high SL value lies proximal to the DF (figure 13c).

The Umtongoi river lies in the eastern most part of the study area and displays a general concave curve with minor convexities along the longitudinal profile. Three zones of high SL values can be discerned in the midstream and downstream 
Table 2. (a) Channel steepness index $\left(k_{s n}\right)$ and (b) valley width to height ratio $\left(V_{f}\right)$ calculated on the longitudinal profile of the four rivers, and the values are classified corresponding to the tectonic activity/uplift.

\begin{tabular}{llll}
\hline River valley & \multicolumn{1}{c}{$\begin{array}{c}k_{\mathrm{sn}} \\
(a)\end{array}$} & Rate of uplift & \multicolumn{1}{c}{$\begin{array}{c}V_{\mathrm{f}} \\
(b)\end{array}$} \\
\hline Jadukata & $400-1827$ & High & $0-0.9$ \\
& $150-399$ & Moderate & $1.0-2.4$ \\
& $<149$ & Low & $>2.5$ \\
Umpung & $300-980$ & High & $0-0.8$ \\
& $100-299$ & Moderate & $0.9-1.9$ \\
& $<99$ & Low & $>2.0$ \\
Umngot & $238-1121$ & High & $0-0.8$ \\
& $80-237$ & Moderate & $0.9-1.5$ \\
& $<79$ & Low & $>1.6$ \\
Umtongoi & $210-805$ & High & $0-0.8$ \\
& $105-209$ & Moderate & $0.9-1.23$ \\
& $<104$ & Low & $>1.24$ \\
\hline
\end{tabular}

segments, the first at 6-7 km (from the source) with SL values ranging between 1300 and 1540, the second at $8 \mathrm{~km}$ with an SL value of 1280 and the third lies between 10 and $11 \mathrm{~km}$ (in the downstream segment) with SL values ranging between 840 and 660 which is proximal to DF (figure 13d).

\subsubsection{Channel steepness index $\left(k_{s n}\right)$}

The normalised steepness values $\left(k_{\mathrm{sn}}\right)$ calculated along the four selected river profiles range from 1 to 1850, which are classified for each river into high, moderate and low values relative to tectonic activity (table 2a). However, the majority of the values are $<90$, with the exception of higher values occurring in isolation, particularly in the vicinity of the knick points (figure 13a-d). Since there is no apparent increase or decrease in the $k_{\mathrm{sn}}$ values along the different lithologic boundaries (dominated by gneisses and granites; figure 1b), thus the role of lithology in $k_{\mathrm{sn}}$ variability (except in the lower alluvial plains) can be discounted. Spatial analysis of the $k_{\mathrm{sn}}$ values indicates an increase in the midstream of the rivers with considerably high values in the downstream segments (figure 13a-d).

The high $k_{\mathrm{sn}}$ values in the midstream correspond to the monoclinal dip of the plateau as suggested by Evans (1964) or the south-facing limb of the anticline as suggested by Clark and Bilham (2008) and the high $k_{\mathrm{sn}}$ values in the downstream segment correspond to the Dauki- Dapsi fault zone. The longitudinal profiles of the south draining rivers indicate a number of knick points or knick zones (figure 13a-d) with numerous small-scale convexities in the river profiles corresponding to high/very high stream gradients (discussed above) as well as high $k_{\mathrm{sn}}$ values suggesting that uplift has outpaced incision (Tyagi et al. 2009).

The convexities observed in the midstream and downstream segments of the channels can be due to the differential uplift (Biswas and Greasemann 2005; Imsong et al. 2016) related to the uplift of the SP since the Miocene period (Clark and Bilham 2008). There is an obvious rise of steepness values in the downstream section where the rivers enter the alluvial plains of Bangladesh and these are orientated along the Dauki-Dapsi fault zone.

\subsubsection{Ratio of the valley floor width $\left(V_{f}\right)$}

The central part of the SP has smooth erosional surfaces, whereas along the highly fractured lithology of the southern margin, the terrain is dissected by deeply incised gorges of $1-1.5 \mathrm{~km}$ deep (Clark and Bilham 2008). The $V_{\mathrm{f}}$ ratio calculated along the four river valleys indicates high values in the upstream segment, whereas in the midstream and downstream segments, the values are close to 0 . Table 2(b) shows the $V_{\mathrm{f}}$ ratios calculated for each river, and the values are classified as high, moderate and low in terms of areas related to active uplift; also the average of the $V_{\mathrm{f}}$ ratios estimated for the upstream valleys gives the highest values ranging from 1.25 to 5.0 , and the middle course values range from 1.3 to 0.5 and downstream $V_{\mathrm{f}}$ ratios range from 0.3 to 0.9 .

\section{Discussion}

Fluvial landforms in the eastern Himalayas are suggested to have been evolved due to the temporal and spatial variability in climate and tectonics (Meetei et al. 2007; Srivastava and Misra 2008; Luirei et al. 2012). In this context, the SP cannot be an exception. As mentioned earlier, the SP is not only tectonically active (Nandy 2001; Kayal et al. 2012) but subjected to exceptionally high rainfall during the ISM (Jennings 1950; Murata et al. 2007). In view of this, it is reasonable to assume that the evolution of the alluvial landforms is an outcome of the cumulative contribution from the steady-state tectonic and cyclical variability in the ISM. There are suggestions that the river courses in the SP are dictated by the numerous major and 
minor tectonic structures present in the plateau (Biswas and Greasemann 2005; Imsong et al. 2016). The present investigation provides the first detailed documentation of the chronologically constrained alluvial succession and their significance towards understanding the role of climate and tectonics.

Implications of climate on valley aggradation: Holocene palaeoclimate records suggest that the ISM was stronger during the early and midHolocene periods (Morrill et al. 2006; Bird et al. 2014), whereas the late Holocene period has been characterised by general aridity. Nonetheless, within this period, there were regional scale fluctuations in ISM precipitation (Yang et al. 2010; Bird et al. 2014). Using sedimentological and geochemical results from the monsoon-dominated Nir' pa Co lake in southeastern Tibet, Bird et al. (2016) suggested two pluvial phases between 3.3 and 2.4 $\mathrm{ka}$, and $1.3 \mathrm{ka}$ and also asserted a brief wet condition during the medieval climatic anomaly between 950 and 800 cal yr BP. Moreover, climatic records suggest changes in the ISM strength during the late Pleistocene to the late Holocene period in the SP, other parts of northeast India and south Asia (Gupta and Thomas 2003; Morrill et al. 2003; Bookhagen et al. 2005; Zhisheng et al. 2011; Berkelhammer et al. 2012; Bird et al. 2014; Dutt et al. 2015; Bird et al. 2016; Imsong et al. 2018). This suggests that variability in climate has been a key for valley aggradation and erosional processes in this region.

The debris flow observed in Ranikor (DF1) and near Kakargora (DF2) was deposited along the sloping mountain front (scarp) of the SP rather than being deposited in the much lower elevated sections near the Bangladesh plains. It is likely that the transportation of the sediments from the south facing scarp towards the slopes was facilitated by gravity during high rainfall events. The reason being debris flow deposits usually occur when the debris-laden hills combine with rainfall run-off and induce mass movements of sediments, rock and water with high velocity speed along the hill slopes (Wohl and Pearthree 1991; Jakob and Hungr 2005). Morphologically, the truncated debris flow observed above the terrace R-T1 in Ranikor suggests that following the deposition of the DF1 in Ranikor, the Jadukata river has aggraded and later modified the terrace surface $\mathrm{R}-\mathrm{T} 1$ on its left bank which is dated to be $1.0 \pm$ $0.07 \mathrm{ka}$, implying that the debris flow is at least older than $1.0 \mathrm{ka}$.
The valleys in the upper reaches of the four rivers studied are narrow and constricted with bedrock lithology with little or no preserved aggradational landforms, and as we move further south into the transitional zone between the mountain front and the alluvial plains of Bangladesh, we find limited fluvially aggraded landforms. Given the fact that the SP is among the wettest places on Earth with an annual average precipitation of $11,000 \mathrm{~mm}$ (Murata et al. 2007), the sediment residence time is significantly low as the sediments are continuously bypassed into the southern lower reaches of the Bangladesh plains.

The chronology and sediment characteristics of the fluvial successions indicate that sediments older than mid-Holocene were bypassed from the study area. The short sediment residence time implies that the Earth's surface processes are operating at a relatively higher pace in the study area. This is expected in tectonically active orogens which are additionally subjected to high intensity rainfall (Bookhagen et al. 2005; Grujic et al. 2006). The PF sequence suggests aggradation of the sediments during the mid- and late Holocene periods, the cause for which can be ascribed to abnormal heavy rainfall activity in the area. The chronology of the PF sequence (5.3 to $4.3 \mathrm{ka}$ ) indicates their deposition during the declining phase of the ISM corresponding to mid-Holocene (Sarkar et al. 2016 and references therein), whereas the youngest flood deposits dated to $0.6 \mathrm{ka}$ indicate the terminal phase of the medieval warm period (MWP) (Lamb 1965; Grove and Switsur 1994). There seems to be a hiatus in the river aggradation process after 4.3 ka and this period coincides well with the study by Berkelhammer et al. (2012) on the Mawmluh cave, Meghalaya which suggests that there was an abrupt shift in the ISM during the late Holocene period in the study area. Our inference on the hiatus in sediment deposition after 4.3 ka further strengthens the concept of a major climatic event (weakening of the ISM or drought events) that occurred around the world starting from $4.2 \mathrm{ka}$ (https://www.bbc. com/news/science-environment-44868527). Subsequently, the flood chronology from the study area indicates that high-magnitude floods were associated with periods of transitional ISM which is surprising, as conventionally the floods in the region are found to be associated with intensified ISM.

Fluvial aggradation in the study area that began around: (i) $\geq 5.3$ ka encompassing the mid-Holocene period weakened the ISM (Sarkar et al. 2016); (i) $4.3 \mathrm{ka}$ regional arid event (Staubwasser et al. 
2003) and late Holocene strengthened the ISM and (iii) around $2.4 \mathrm{ka}$ continued intermittently until 1.0-0.3 ka, encompassing the MWP and the Little Ice Age (LIA) (Lamb 1965; Bradely and Jones 1993; Yadav et al. 2009).

These age estimates suggest three pluvial phases during the late Holocene period in the SP, i.e., (i) $5.3-4.3 \mathrm{ka}$; (ii) $2.4-1.0 \mathrm{ka}$ and (ii) $0.7-0.3 \mathrm{ka}$. This would imply that the rivers flowing in areas of intensified monsoon such as the SP are concomitant with the regional fluctuations of the ISM indicating that the climate of the SP is influenced by short-term global palaeo-climatic perturbations which lasted for a few centuries. Based on the geomorphic disposition of the fluvial landforms in the southern part of SP, it can be suggested that the debris flow deposits are the oldest landforms in the study area followed by the PF deposits $(5.3-0.6 \mathrm{ka})$ and fluvial terraces D-T1s $(2.4-0.3$ $\mathrm{ka})$, whereas the AFs seem to be the youngest landforms $(0.6 \mathrm{ka})$. Figure 14 illustrates the evolution of fluvial landforms in the southern part of the SP bordered with Bangladesh. The optical chronology of the phases of alluviation correlates reasonably well with the monsoon reconstruction based on speleothem data available from Dongee caves (Yuan et al. 2004) and a high-resolution monsoon reconstruction from eastern India by Yadava and Ramesh (2005) implying that the event was regional in nature.

Implications of active tectonics: Morphologically, the south-vergent SP is a differentially uplifting terrain as compared to the tapering northern front (Clark and Bilham 2008). The river patterns and lineament study show that the drainage system in the SP follows the numerous structures present in the plateau (Biswas and Greasemann 2005; Imsong 2017); however, the antiquity of these structures are debated (Khattri et al. 1983; Gupta and Sen 1988; Chen and Molnar 1990; Kumar et al. 1996; Srivastava et al. 2005). Subsequently, considering that the plateau lies in a monsoondominated area (Jennings 1950; Bookhagen et al. 2005; Murata et al. 2007), erosion seems to have played a key role in valley aggradation and reshaping the topography during the Holocene. Nonetheless, the channel segments delimited by numerous knick points and slopes (topographic breaks in the longitudinal profiles) with associated anomalously high stream gradients and high channel steepness indexes in the downstream part of the rivers draining into the southern alluvial plain indicate

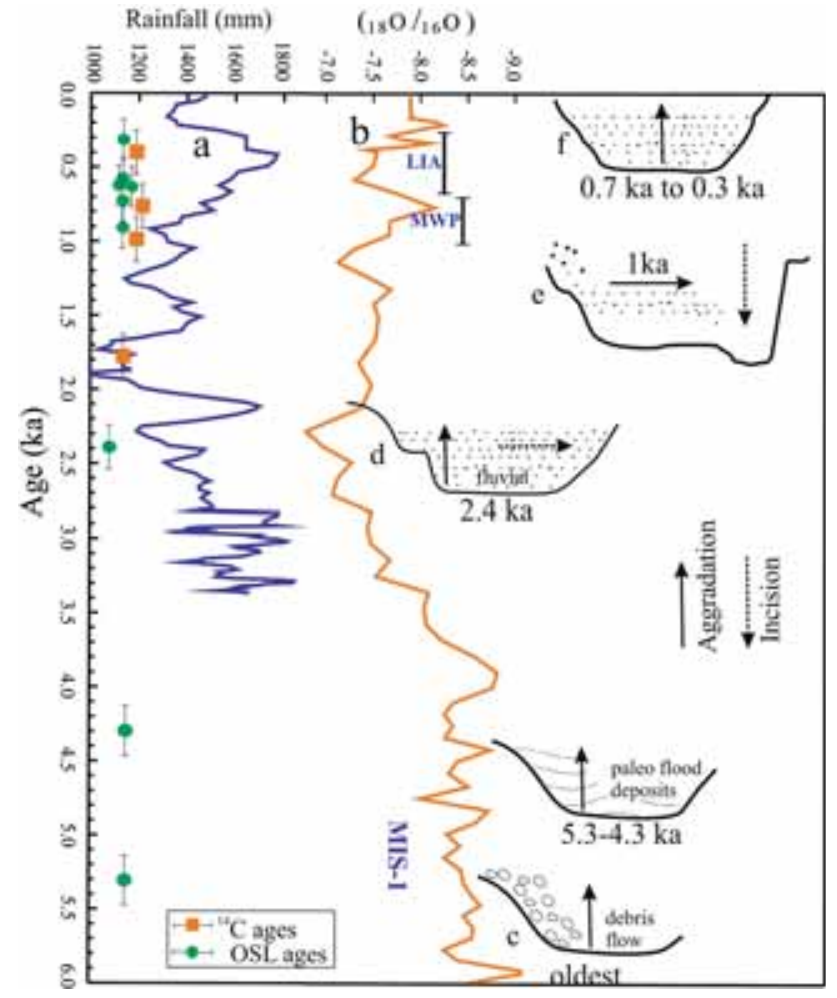

Figure 14. The events reconstructed from the study area are plotted against the climate proxies (oxygen isotopic data) representing the ISM variability. (a) The ISM reconstruction based on the speleothem record from Gupteswar cave (Yadava and Ramesh 2005). (b) From Dongee cave characterizing the Asian summer monsoon variability (Yuan et al. 2004). Note that the debris flows (c) in the study area occurred during period of weak ISM, whereas the events of fluvial aggradations (d, e and $\mathbf{f}$ ) were associated with relative enhancement of ISM. The incision occurred during brief interlude corresponding to weak ISM.

an appreciable oblique/thrust-related movement. For example, morphometric indices such as low $V_{\mathrm{f}}$ values obtained in the midstream and downstream sections (the Dauki-Dapsi fault zone) of all rivers (table 2) indicate actively incising river valleys relative to the crustal deformation denoted by V-shaped river valleys. Additionally, there is an obvious pattern of high steepness index followed by high stream gradient along the Dauki-Dapsi fault zone. The high steepness values are corroborations of localised uplifts with respect to the DF zone and accord well with the earlier studies (Biswas and Greasemann 2005; Clark and Bilham 2008). This is also supported by the morphotectonic indices analysed in the southern part of the SP by Imsong et al. (2016) which suggests a higher surface uplift in the central part and preferential eastward tilting of the plateau indicating episodic activity along the Dauki-Dapsi fault zone. 
Linear valleys are troughs that are developed because of the continued movement along strikeslip faults (Keller and Pinter 2002; Goudie 2004). Our analysis of the linear valleys which are delimited by linear ridges (which are more eroded to the west as compared to the eastern side) between Shipapara and Balat suggests that these are an eloquent geomorphic expression of continued lateral movement along the $\mathrm{E}-\mathrm{W}$ trending $\mathrm{DF}$ zone. Continued lateral movements in a strikeslip fault setting consists of a localised area of convergence (restraining bends) and divergence (releasing bends); these bends are also characterised by oblique deformation. The restraining bends are sites of topographic uplift and releasing bends are sites of subsidence (Cunningham and Mann 2007). Drainages tend to occupy a minimum resistance path which in the present case is the fractured/pulverised fault zone (Francisco and Mateo 2016). Along the DF, the activity of the fault is reflected in the right lateral deflection of river channels that drain through the linear valleys (Imsong et al. 2016). The absence of a large E-W trending drainage system (sympathetic to the linear valley trend) further supports the suggestion that the antiquity of the linear valleys are significantly older compared to the small streams that currently flow through them. We suggest that the linear valleys were formed during the enhanced tectonic instability linked with the activity along the Dauki-Dapsi fault zone which led to the growth of strike-slip splays (lateral extension) and associated oblique deformation (uplift). These features were subsequently modified by continued erosion giving rise to the present day linear valleys.

Analyses of the AFs studied along the southern front of the SP at the Umpung, Umngot and Umtongoi rivers show distinct asymmetric morphology with a preferential eastward tilting (figures 6-8), and are inclined towards the NW-SE and NNW-SSE directions. In Dauki, the regional slope of the area is towards the west, whereas the older alluvial fan (D-AF) terrace shows a tilting of $\sim 5-8^{\circ}$ towards the east with the presence of a $\sim 4 \mathrm{~m}$ deep AF scarp (figure $7 \mathrm{c}$ ). The D-AF is dated to be $0.6 \pm 0.05 \mathrm{ka}$, whereas the younger untilted D-T1 terrace is dated to be $0.3 \pm 0.02 \mathrm{ka}$, implying that the tilting of D-AF occurred after $0.6 \mathrm{ka}$ and before $0.3 \mathrm{ka}$. Although the antiquity and kinematics of the boundary faults in the SP are debated, it is evident that the SP is a southvergent fold structure, the remnants of which can be observed along the SMF geomorphologically represented by the linear ridges. Our investigations through the tectono-morphometric indices support the idea that there has been significant lateral (strike-slip) and uplift (thrusting)-related deformation along the mountain front during the late Holocene period.

\section{Conclusion}

The southern front of the SP has preserved three pluvial stages during the mid-late Holocene, the oldest is assigned to be (i) 5.3 to $4.3 \mathrm{ka}$ which indicates their deposition during the declining phase of the ISM corresponding to the mid-Holocene (ii) 2.4 to 1.0 ka represents the late Holocene period strengthened ISM and (iii) 0.7 to 0.3 ka encompasses the MWP and LIA. Thus the present study indicates that valley aggradation and evolution of landforms began around the mid-Holocene, followed by a short period of hiatus (after $4.3 \mathrm{ka}$ ) in the deposition of sediments during the (early) late Holocene period. And with the beginning of late Holocene strengthening of ISM re-deposition of the sediments commenced and intermittently continued till the MWP and LIA.

The flood chronology from the study area shows that high-magnitude floods were associated with periods of transitional ISM which is surprising, as conventionally and at present, the floods in the region have been found to be associated with intensified ISM. Whereas the occurrence of E-W trending linear valleys and ridges are ascribed to the lateral deformation (sedimentation) and the accompanied oblique movement associated with the Dauki-Dapsi fault zone. Morphotectonic investigations on the four south flowing rivers show significant thrust-related deformation upstream of the mountain front. The activity continued until the late Holocene period, and this is eloquently manifested by the tilted AF which is dated to be $0.6 \mathrm{ka}$.

\section{Acknowledgements}

WI acknowledges the SRF-NET fellowship (File no: 09/420/(0002)/2012-EMR-I) from the CSIRHRDG. The authors thank Wadia Institute of Himalayan Geology (WIHG), Dehradun and Gauhati University for the research facilities. WI is grateful to WIHG, Dehradun and Dr Navin Juyal, Physical Research Laboratory, Ahmedabad for the analysis of the optical ages. The authors would also 
like to thank the two anonymous reviewers whose critical comments and suggestions have helped in improving the manuscript.

\section{References}

An Y, Dubey C S, Webb A A G, Kelty T K, Grove M, Gehrels G E and Burgess W P 2010 Geologic correlation of the Himalayan orogen and Indian craton: Part 1. Structural geology, U-Pb zircon geochronology and tectonic evolution of the Shillong Plateau and its neighboring regions in NE India; Geol. Soc. Am. Bull. 122 336-359.

Beaumont C, Jamieson R A, Nguyen M H and Lee B 2001 Himalayan tectonics explained by extrusion of a low-viscosity crustal channel coupled to focused surface denudation; Nature 414(6865) 738-742.

Berkelhammer M, Sinha A, Stott L, Cheng H, Pausata F S R and Yoshimura K 2012 An abrupt shift in the Indian monsoon 4000 years ago; Climates, Landscapes, Civilizations Geophys. Monogr. Ser. 198(75-87), https://doi.org/10. 1029/2012GM001207.

Bilham R and England P 2001 Plateau pop-up during the great 1897 Assam earthquake; Nature 410 806-809.

Bird B W, Polisar P J, Lei Y, Thompson L G, Yao T, Finney B P, Bain D J, Pompeani D P and Steinman B A 2014 A Tibetan lake sediment record of Holocene Indian summer monsoon variability; Earth Planet. Sci. Lett. 399 92-102.

Bird B W, Lei Y, Perello M, Polissar P J, Yao T, Finney B, Bain D, Pompeani D and Thompson L G 2016 LateHolocene Indian summer monsoon variability revealed from a 3300-year-long lake sediment record from Nir'pa Co, southeastern Tibet; Holocene 27(4) 541-552, https:// doi.org/10.1177/0959683616670220.

Biswas S and Greasemann B 2005 Structural modelling of the subsurface geology of the Sylhet trough, Bengal Basin; Bangladesh Geosci. J. 11 19-33.

Bookhagen B, Thiede R C and Strecker M R 2005 Abnormal monsoon years and their control on erosion and sediment flux in the high, arid northwest Himalaya; Earth Planet. Sci. Lett. 231(1) 131-146.

Bookhagen B, Fleitmann D, Nishiizumi K, Strecker M R and Thiede R C 2006 Holocene monsoonal dynamics and fluvial terrace formation in the northwest Himalaya, India; Geology 34(7) 601-604.

Bøtter-Jensen L, Thomsen K J and Jain M 2010 Review of optically stimulated luminescence (OSL) instrumental developments for retrospective dosimetry; Radiat. Meas. 45(3) 253-257.

Bradely R S and Jones P D 1993 'Little Ice Age' summer temperature variations: Their nature and relevance to recent global warming trend; Holocene $\mathbf{3 ( 4 )} 367-$ 376.

Braun J and Sambridge M 1997 Modelling landscape evolution on geological time scales: A new method based on irregular spatial discretization; Basin Res. 9(1) 27-52.

Bridgland D R and Westaway R 2008 Preservation patterns of late cenozoic fluvial deposits and their implications: Results from IGCP 449; Quat. Inter. 189(1) 5-38.

Bull W B 1977 Tectonic geomorphology of the Mojave desert: US geological survey contract report 14-08-001-G-394,
Office of Earthquakes, Volcanoes, and Engineering, Menlo Park, California, 188p.

Bull W B and McFadden L D 1977 Tectonic geomorphology north and south of the garlock fault, California; In: Geomorphology in arid regions. Proceedings of the eighth annual geomorphology symposium, State University of New York, Binghamton, pp. 115-138.

Burbank D W and Anderson R S 2001 Tectonic Geomorphology (1st edn); Blackwell Science Ltd., New York.

Burbank D W, Blythe A E, Putkonen J, Pratt-Sitaula B, Gabet E, Oskin M, Barros A and Ojha T P 2003 Decoupling of erosion and precipitation in the Himalayas; Nature 426(6967) 652-655.

Chandel H N, Patel A D, Vaghela H R and Ubale G P 2006 An effective and reusable sampling pipe for luminescence dating; Ancient TL 24(1) 21-22.

Chatterjee N, Mazumdar A C, Bhattacharya A and Saikia R R 2007 Mesoproterozoic granulites of the ShillongMeghalaya Plateau: Evidence of westward continuation of the Prydz Bay Pan-African suture into Northeastern India; Precamb. Res. 152 1-26.

Chaudhary S, Shukla U K, Sundriyal Y P, Srivastava P and Jalal P 2015 Formation of paleo valleys in the central Himalaya during valley aggradation; Quat. Inter. 371 $254-267$.

Chen W P and Molnar P 1990 Source parameters of earthquakes and intraplate deformation beneath the Shillong Plateau and the Northern Indo-Burman ranges; J. Geophys. Res. 95(B8) 12527-12552.

Chen Y C, Sung Q and Cheng K-Yu 2003 Along-strike variations of morphotectonic features in the western foothills of Taiwan: Tectonic implications based on streamgradient and hypsometric analysis; Geomorphology $\mathbf{5 6}$ 109-137.

Clark M K and Bilham R 2008 Miocene rise of the Shillong Plateau and the beginning of the end for the Eastern Himalaya; Earth Planet. Sci. Lett. 269 336-350.

Cunningham W D and Mann P 2007 Tectonics of strike-slip restraining and releasing bends; Geol. Soc. London, Spec. Publ. 290(1) 1-12.

Dasgupta A B and Biswas A K 2000 Geology of Assam; (1st edn) Geol. Soc. India, Bangalore, 167p, ISBN No: 81-85867-44-5.

Davis W M 1899 The geographical cycle; Geogr. J. 14(5) 481-504.

Duarah B P and Phukan S 2011 Understanding the tectonic behavior of Shillong Plateau, India, using Remote Sensing Data; Geol. Soc. Ind. 77 105-112.

Dutt S, Gupta A K, Clemens S C, Hai C, Singh R K, Kathayat G and Edwards R L 2015 Abrupt changes in Indian summer monsoon strength during 33,800 to 5500 years B.P; Geophys. Res. Lett. 42 5526-5532.

Dutta S, Suresh N and Kumar R 2012 Climatically controlled late quaternary terrace staircase development in the fold-and-thrust belt of the Sub Himalaya; Paleogeogr. Paleoclimatol. Paleoecol. 356 16-26.

Duvall A, Kirby E and Burbank D 2004 Tectonic and lithologic controls on bedrock channel profiles and process in coastal California; J. Geophys. Res. 109 F03002.

Evans P 1964 The tectonic framework of Assam; Geol. Soc. India 5 80-96. 
Francisco G and Mateo G 2016 Landforms of the Earth: An Illustrated Guide; Springer International Publishing, Switzerland, https://doi.org/10.1007/978-3-319-26947-4.

Geological Survey of India (GSI) 2009 Meghalaya. Miscellaneous publication No. 30 part iv, Vol. 2(ii).

Ghosh S, Fallick A E, Paul D K and Potts P J 2005 Geochemistry and origin of Neoproterozoic Granitoids of Meghalaya, Northeast India: Implications for linkage with amalgamation of Gondwana supercontinent; Gondwana Res. 8(3) 421-432.

Goudie A S 2004 Encyclopaedia of geomorphology; Routledge Ltd., London and New York, 1036p.

Grove J M and Switsur R 1994 Glacial geological evidence for the medieval warm period; Clim. Change 26(2-3) 143169.

Grujic D, Coutand I, Bookhagen B, Bonnet S, Blythe A and Duncan C 2006 Climatic forcing of erosion, landscape, and tectonics in the Bhutan Himalayas; Geology 34(10) 801-804.

Gupta A K and Thomas E 2003 Initiation of Northern Hemisphere glaciation and strengthening of the northeast Indian monsoon: Ocean Drilling Program Site 758, eastern equatorial Indian ocean; Geol. Soc. Am. 31(1) $47-50$.

Gupta R P and Sen A K 1988 Imprints of the Ninety-East ridge in the Shillong Plateau, Indian shield; Tectonophys. $154335-341$.

Hack J T 1957 Studies of longitudinal stream profiles in Virginia and Maryland; Geol. Surv. professional paper 294-B, pp. $45-95$.

Hack J T 1973 Stream-profile analysis and stream-gradient index; J. Res. US Geol. Surv. 1(4) 421-429.

Hancock G S and Anderson R S 2002 Numerical modelling of fluvial strath-terrace formation in response to oscillating climate; Geol. Soc. Am. Bull. 114(9) 1131-1142.

Hodges K V, Hurtado J M and Whipple K X 2001 Southward extrusion of Tibetan crust and its effect on Himalayan tectonics; Tectonics 20(6) 799-809.

Hodges K V, Wobus C, Ruhl K, Schildgen T and Whipple K 2004 Quaternary deformation, river steepening, and heavy precipitation at the front of the Higher Himalayan ranges; Earth Planet. Sci. Lett. 220(3) 379-389.

Imsong W 2017 Geomorphological appraisal of neotectonic activities in the Shillong Plateau, NE India; PhD Thesis, Gauhati University, Assam, India.

Imsong W, Choudhury S and Phukan S 2016 Ascertaining the neotectonic activities in the southern part of Shillong Plateau through geomorphic parameters and remote sensing data; Curr. Sci. 110 91-98.

Imsong W, Choudhury S, Phukan S and Duarah B P 2018 Morphodynamics of the Kulsi River Basin in the northern front of Shillong Plateau: Exhibiting episodic inundation and channel migration; J. Earth Syst. Sci. 1275.

Islam M S, Ryuichi Shinjo and Kayal J R 2011 Popup tectonics of the Shillong Plateau in northeastern India: Insight from numerical simulations; Gondwana Res., https://doi.org/10.1016/j.gr.2010.11.007.

Jakob M and Hungr O 2005 Debris-Flow Hazards and Related Phenomena; Springer-Verlag, Berlin, Heidelberg, New York, 739p.

Jennings A H 1950 World's greatest observed point rainfall; Mon. Weather Rev. 78 4-5.
Juyal N, Kar A, Rajaguru S N and Singhvi A K 2003 Luminescence chronology of aeolian deposition during the late quaternary on the southern margin of Thar Desert, India; Quat. Int. 104 87-98.

Juyal N, Chamyal L S, Bhandari S, Bhushan R and Singhvi A K 2006 Continental record of the southwest monsoon during the last 130ka: Evidence from the southern margin of the Thar Desert, India; Quat. Sci. Rev. 25(19) 26322650.

Juyal N, Sundriyal Y P, Rana N, Chaudhary S and Singhvi A K 2010 Late quaternary fluvial aggradation and incision in the monsoon-dominated Alaknanda valley, Central Himalaya, Uttarakhand, India; J. Quat. Sci. 251293 1304.

Kayal J R 1987 Microseismicity and source mechanism study: Shillong Plateau, northeast India; Bull. Seismol. Soc. Am. 77 184-194.

Kayal J R and De Reena 1991 Microseismicty and tectonic in NorthEast India; Bull. Seismol. Soc. Am. 81(1) 131-138.

Kayal J R, Arefiev S S, Barua S, Hazarika D, Gogoi N, Kumar A, Chowdhury S N and Kalita S 2006 Shillong plateau earthquakes in the northeast India region: Complex tectonic model; Curr. Sci. 91(1) 109-114.

Kayal J R, Arefiev S S, Barua S, Hazarika D, Gogoi N, Gautam J L, Barauah S, Dorbath C and Tatevossia R 2012 Large and great earthquakes in the Shillong PlateauAssam valley area of Northeast India Region: Pop-up and transverse tectonics; Tectonophys. 532 186-192.

Keller E A and Pinter N 2002 Active tectonics: Earthquake, uplift, and landscape; 2nd edn, Prentice Hall, Englewood Cliffs, pp. 121-147.

Khattri K N, Wyss M, Gaur V K, Saha S N and Bansal V K 1983 Local seismicity in the region of Assam gap, northeast India; Bull. Seismol. Soc. Am. 73 459469.

Kirby E and Whipple K X 2001 Quantifying differential rockuplift rates via stream profile analysis; Geol. Soc. Am. 29(5) 415-418.

Kirby E, Whipple K X, Tang W and Chen Z 2003 Distribution of active rock uplift along the eastern margin of the Tibetan plateau: Inferences from bedrock channel longitudinal profiles; J. Geophys. Res. 108(B4) 2217.

Kothyari G C, Shukla A D and Juyal N 2016 Reconstruction of late quaternary climate and seismicity using fluvial landforms in Pindar River valley, Central Himalaya, Uttarakhand, India; Quat. Int., https://doi.org/10.1016/ j.quaint.2016.06.001.

Kumar D, Mamallan R and Dwivedy K K 1996 Carbonatite magmatism in northeast India; J. Southeast Asian Earth Sci. 13(2) 145-158.

Lamb H H 1965 The early medieval warm epoch and its sequel; Paleogeogr. Paleoclimatol. Paleoecol. 1 13-37.

Leopold L B and Maddock T Jr 1953 The hydraulic geometry of stream channels and some physiographic implications; Geol. Surv. Professional Paper 252.

Luirei K, Bhakuni S S, Srivastava P and Suresh N 2012 Late pleistocene-holocene tectonic activities in the frontal part of NE Himalaya between Siang and Dibang river valleys, Arunachal Pradesh, India; Z. Geomorphol. 56(4) $477-$ 493.

Mackin H J 1948 Concept of the Graded River; Geol. Soc. Am. 55 463-512. 
Meetei L I, Pattanayak S K, Bhaskar A, Pandit M K and Tandon S K 2007 Climatic imprints in quaternary valley fill deposits of the middle Teesta valley, Sikkim Himalaya; Quat. Int. 159 32-46.

Morrill C, Jonathan T O and Cole J E 2003 A synthesis of abrupt changes in the Asian summer monsoon since the last deglaciation; Holocene 13(4) 465-476.

Morrill C, Overpeck J T, Cole J E, Liu K, Shen C and Tang L 2006 Holocene variations in the Asian monsoon inferred from the geochemistry of lake sediments in central Tibet; Quat. Res. 65 232-243.

Murata F, Hayashi T, Matsumoto J and Asada H 2007 Rainfall on the Meghalaya Plateau in the north eastern India-one of the rainiest places in the world; Nat. Hazards 42 391-399.

Murray A S and Wintle A G 2000 Luminescence dating of quartz using an improved single-aliquot regenerative-dose protocol; Radiat. Meas. 32(1) 57-73.

Nandy D R 2001 Geodynamics of Northeastern India and the Adjoining Region; ACB Publications, Kolkata.

Nandy D R and Dasgupta S 1991 Seismotectonic domains of northeastern India and adjacent areas; Phys. Chem. Earth $18371-384$.

Oldham R D 1899 Report on the great earthquake of 12 June 1897, memoir; Geol. Soc. India 29379.

Phartiyal B, Sharma A, Upadhyay R and Sinha A K 2005 Quaternary geology, tectonics and distribution of paleoand present fluvio/glacio lacustrine deposits in Ladakh, NW Indian Himalaya - a study based on field observations; Geomorphology 65(3) 241-256.

Pratt-Sitaula B, Burbank D W, Heimsath A and Ojha T 2004 Landscape disequilibrium on 1000-10,000 year scales Marsyandi River, Nepal, central Himalaya; Geomorphology 58(1) 223-241.

Prescott J R and Hutton J T 1994 Cosmic ray contributions to dose rates for luminescence and ESR dating: Large depths and long-term time variations; Radiat. Meas. 23(2-3) 497-500.

Rajendran C P, Rajendran K, Duarah B P, Baruah S and Earnest A 2004 Interpreting the style of faulting and paleoseismicity associated with the 1897 Shillong, northeast India, earthquake: Implications for regional tectonism; Tectonics 23 TC4009.

Ray Y and Srivastava P 2010 Widespread aggradation in the mountainous catchment of the Alaknanda-Ganga river system: Timescales and implications to Hinterlandforeland relationships; Quat. Sci. Rev. 29(17) 2238-2260.

Reiners P W, Ehlers T A, Mitchell S G and Montgomery D R 2003 Coupled spatial variations in precipitation and long-term erosion rates across the Washington cascades; Nature 426(6967) 645-647.

Roe G H, Montgomery D R and Hallet B 2002 Effects of orographic precipitation variations on the concavity of steady-state river profiles; Geology 30(2) 143-146.

Sarkar A, Mukherjee A D, Bera M K, Das B, Juyal N, Morthekai P, Deshpande R D, Shinde V S and Rao L S 2016 Oxygen isotope in archaeological bioapatites from India: Implications to climate change and decline of Bronze Age Harappan civilization; Sci. Rep. 6 26555.

Sato T 2013 Mechanism of orographic precipitation around the Meghalaya Plateau associated with intraseasonal oscillation and the diurnal cycle; Mon. Weather Rev. 141(7) 2451-2466.

Seeber L and Armbruster J 1981 Great detachment earthquakes along the Himalaya arc and long term forecasts; In: Earthquake Prediction: An International Review, Maurice Ewing Series (eds) D W Simpson and P G Richards, Am. Geophys. Union, Washington, DC, 4 259277.

Sharma R, Gouda H C, Singh R K and Nagaraju B V 2012 Structural study of Meghalaya Plateau through Aeromagnetic data; J. Geol. Soc. India 791129.

Sharma S, Chand P, Bisht P, Shukla A D, Bartarya S K, Sundriyal Y P and Juyal N 2016 Factors responsible for driving the glaciation in the Sarchu Plain, eastern Zanskar Himalaya, during the late quaternary; J. Quat. Sci. 31(5) 495-511.

Shukla A D, Bhandari N and Shukla P N 2002 Chemical signatures of the Permian-Triassic transitional environment in Spiti Valley, India; Geol. Soc. Am. Spec. Paper 356 445-454.

Snyder N P, Whipple K X, Tucker G E and Merritts D J 2000 Landscape response to tectonic forcing: Digital elevation model analysis of stream profiles in the Medocino triple junction region, northern California; Geol. Soc. Am. Bull. 112 (8) 1250-1263.

Srivastava P and Misra D K 2008 Morpho-sedimentary records of active tectonics at the Kameng River exit, NE Himalaya; Geomorphology 97 187-198.

Srivastava R K, Heaman L M, Sinha A K and Shihua S 2005 Emplacement age and isotope geochemistry of Sung Valley alkaline-carbonatite complex, Shillong Plateau, northeastern India: Implications for primary carbonate melt and genesis of the associated silicate rocks; Lithos 81(1) 33-54.

Srivastava P, Kumar A, Mishra A, Meena N K, Tripathi J K, Sundriyal Y P, Agnihotri R and Gupta A K 2013 Early Holocene monsoonal fluctuations in the Garhwal higher Himalaya as inferred from multi-proxy data from the Malari paleolake; Quat. Res. 80(3) 447-458.

Stark C P and Stark G J 2001 A channelization model of landscape evolution; Am. J. Sci. 301 486-512.

Starkel L 2003 Climatically controlled terraces in uplifting mountain areas; Quat. Sci. Rev. 22 2189-2198.

Staubwasser M, Sirocko F, Grootes P M and Segl M 2003 Climate change at the $4.2 \mathrm{ka} \mathrm{BP}$ termination of the Indus valley civilization and Holocene south Asian monsoon variability; Geophys. Res. Lett. 30 1425-1429.

Thiede R C, Bookhagen B, Arrowsmith J R, Sobel E R and Strecker M R 2004 Climatic control on rapid exhumation along the Southern Himalayan Front; Earth Planet. Sci. Lett. 222(3) 791-806.

Tyagi A K, Chaudhary S, Rana N, Sati S P and Juyal N 2009 Identifying areas of differential uplift using steepness index in the Alaknanda basin, Garhwal Himalaya, Uttarakhand; Curr. Sci. 97(10) 1473-1477.

Vandenberghe J 2003 Climate forcing of fluvial system development: An evolution of ideas; Quat. Sci. Rev. 22(20) 2053-2060.

Verma R K, Mukhopadhyay M and Ahluwalia M S 1976 Seismicity, gravity and tectonics of Northeast India and Northern Burma; Bull. Seismol. Soc. Am. 66(5) 16831694 . 
Wobus C W, Hodges K V and Whipple K X 2003 Has focused denudation sustained active thrusting at the Himalayan topographic front?; Geology 31(10) 861-864.

Wohl E E and Pearthree P P 1991 Debris flows as geomorphic agents in the Huachuca Mountains of southeastern Arizona; Geomorphology 4(3-4) 273-292.

Yadav R R, Braeuning A and Singh J 2009 Tree ring inferred summer temperature variations over the last millennium in western Himalaya, India; Clim. Dyn., https://doi.org/ 10.1007/s00382-009-0719-0.

Yadava M G and Ramesh R 2005 Monsoon reconstruction from radiocarbon dated tropical Indian speleothems; Holocene 15(1) 48-59.

Corresponding editor: NAVIN JUYAL
Yang B, Qin C, Huang K, Fan Z and Liu J 2010 Spatial and temporal patterns of variations in tree growth over the northeastern Tibetan plateau during the period AD 1450-2001; Holocene 20(8) 1235-1245.

Yuan D, Cheng H, Edwards R L, Dykoski C A, Kelly M J, Zhang M, Qing J, Lin Y, Wang Y, Wu J and Dorale J A 2004 Timing, duration, and transitions of the last interglacial Asian monsoon; Science 304(5670) 575-578. Zhisheng A, Clemens S C, Shen J, Qiang X, Zhangdong J, Sun Y, Prell W L, Luo J, Wang S, Xu H, Cai Y, Zhou W, Liu X, Liu W, Shi Z, Yan L, Xiao X, Chang H, Wu F, AI Li and Lu F 2011 Glacial-Interglacial Indian summer monsoon dynamics; Science 333 719-723. 